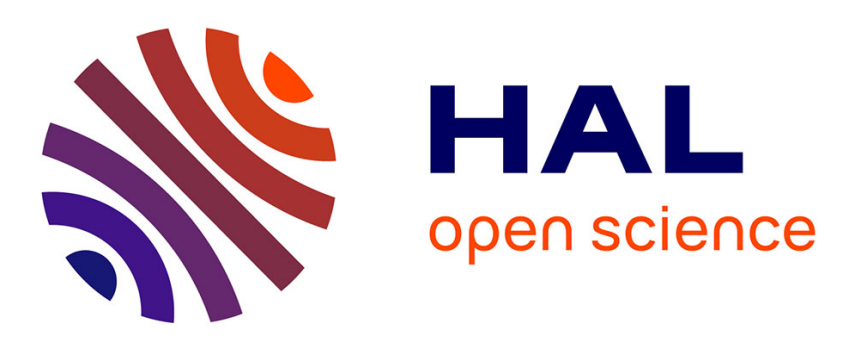

\title{
IsoCombretaQuinazolines: Potent Cytotoxic Agents with Antitubulin Activity
}

Mohamed Ali Soussi, Olivier Provot, Guillaume Bernadat, Jérôme Bignon,

Déborah Desravines, Joëlle Dubois, Jean-Daniel Brion, Samir Messaoudi, Mouad Alami

\section{To cite this version:}

Mohamed Ali Soussi, Olivier Provot, Guillaume Bernadat, Jérôme Bignon, Déborah Desravines, et al.. IsoCombretaQuinazolines: Potent Cytotoxic Agents with Antitubulin Activity. ChemMedChem, 2015, 10 (8), pp.1392-1402. 10.1002/cmdc.201500069 . hal-02394367

\section{HAL Id: hal-02394367 https://hal.science/hal-02394367}

Submitted on 4 Dec 2019

HAL is a multi-disciplinary open access archive for the deposit and dissemination of scientific research documents, whether they are published or not. The documents may come from teaching and research institutions in France or abroad, or from public or private research centers.
L'archive ouverte pluridisciplinaire HAL, est destinée au dépôt et à la diffusion de documents scientifiques de niveau recherche, publiés ou non, émanant des établissements d'enseignement et de recherche français ou étrangers, des laboratoires publics ou privés. 
archives-ouvertes

\section{Iso CombretaQuinazolines: Potent Cytotoxic Agents with Antitubulin Activity}

Mohamed Ali Soussi, Olivier Provot, Guillaume Bernadat, Jérôme Bignon,

Déborah Desravines, Joëlle Dubois, Jean-Daniel Brion, Samir Messaoudi, Mouad Alami, Mohamed Soussi

\section{To cite this version:}

Mohamed Ali Soussi, Olivier Provot, Guillaume Bernadat, Jérôme Bignon, Déborah Desravines, et al.. Iso CombretaQuinazolines: Potent Cytotoxic Agents with Antitubulin Activity. ChemMedChem, Wiley-VCH Verlag, 2015, 10 (8), pp.1392-1402. 10.1002/cmdc.201500069 . hal-02394367

\section{HAL Id: hal-02394367 \\ https://hal.archives-ouvertes.fr/hal-02394367}

Submitted on 4 Dec 2019

HAL is a multi-disciplinary open access archive for the deposit and dissemination of scientific research documents, whether they are published or not. The documents may come from teaching and research institutions in France or abroad, or from public or private research centers.
L'archive ouverte pluridisciplinaire HAL, est destinée au dépôt et à la diffusion de documents scientifiques de niveau recherche, publiés ou non, émanant des établissements d'enseignement et de recherche français ou étrangers, des laboratoires publics ou privés. 


\title{
IsoCombretaQuinazolines: Potent Cytotoxic Agents with Antitubulin Activity
}

\author{
Mohamed Ali Soussi, ${ }^{[a]}$ Olivier Provot, ${ }^{[a]}$ Guillaume Bernadat, ${ }^{[a]}$ Jérome Bignon, ${ }^{[b]}$ \\ Déborah Desravines, ${ }^{[b]}$ Joëlle Dubois, ${ }^{[b]}$ Jean-Daniel Brion, ${ }^{[a]}$ Samir Messaoudi, ${ }^{*}[a]$ \\ Mouad Alami*[a]
}

\begin{abstract}
A series of novel isocombretaquinazolines (isoCoQ) 4 was quickly prepared using the coupling of $\mathrm{N}$-tosylhydrazones with 4-chloroquinazolines under palladium catalysis. These compounds, which could be regarded as isoCA-4 analogues devoid of the 3,4,5-trimethoxyphenyl ring, displayed a nanomolar level of cytotoxicity against various human cancer cells and inhibited tubulin polymerization effectively. IsoCoQ $\mathbf{4 b}, \mathbf{4 c}$ and $\mathbf{4 d}$ having the greatest ressemblance to isoCA-4, isoFCA-4 and
\end{abstract}

\section{Introduction}

Combretastatin A-4 (CA-4, Figure 1), a cis-stilbene isolated from the South African tree Combretum caffrum, ${ }^{[1]}$ strongly inhibits tubulin assembly by binding at the colchicine site. ${ }^{[2]}$ CA-4 is also a highly cytotoxic agent at a nanomolar concentration against a variety of cancer cells, including multidrug-resistant cell lines. [ 3,4 ] Several studies have demonstrated that $\mathrm{CA}-4$, by binding to $\beta$-tubulin, has deleterous effects on tumor vasculature causing a rapid vascular shutdown which led to central tumor necrosis. ${ }^{[5,6]}$ However, this stilbene of very simple chemical structure, suffers from several drawbacks such as a low water solubility and a chemical instability of its Z-double bond, [7] which isomerizes during storage, administration ${ }^{[8]}$ and metabolism. ${ }^{[9]}$ The first drawback has been resolved by the synthesis of a phosphate water-soluble prodrug (CA-4P, fosbretabulin) and a serinamido derivative (AVE-8062, ombrabulin) which also cause vascular shutdown and reduction in tumor blood flow in vivo. These pro-drugs are currently used in clinical trials for

[a] Dr. M.A. Soussi, Dr. O. Provot, Dr. S. Messaoudi, Dr. G. Bernadat Pr. J.-D. Brion, Dr. M. Alami

Univ. Paris-Sud, CNRS, BioCIS-UMR 8076, Laboratoire de Chimie Thérapeutique, Equipe Labellisée Ligue Contre le Cancer, LabEx LERMIT, Faculté de Pharmacie, 5 rue J.-B. Clément, ChâtenayMalabry, F-92296, France

Fax: (+33) 1.46.83.58.28, E-mail: olivier.provot@u-psud.fr; samir.messaoudi@u-psud.fr; mouad.alami@u-psud.fr

[b] Dr. J. Bignon, Dr. D. Desravines, Dr. J. Dubois Institut de Chimie des Substances Naturelles, UPR 2301, CNRS, avenue de la Terrasse, F-91198 Gif sur Yvette, France

Supporting information for this article is available on the WWW under http://www.chemmedchem.org or from the author. iso $\mathrm{NH}_{2} \mathrm{CA}-4$, respectively, led to the arrest of HCT116 cancer cell lines in the $G_{2} / M$ phase of the cell cycle at a very low concentration. Preliminary in vitro antivascular results showed that 4d has disrupted a network of capillary-like structures formed by human umbilical vein endothelial cells on Matrigel. All of these results clearly demonstrated that the replacement of the 3,4,5trimethoxyphenyl ring of isoCA-4 by a quinazoline nucleus is possible and leads to new highly promising derivatives of potential for further development as antitubulin agents.

advanced anaplastic thyroid carcinoma, even if some vascular side effects ${ }^{[10,11]}$ were reported. Concerning the instability of the Z-double bond, a significant effort has been undertaking to develop CA-4 analogues in which the stilbene double bond was inserted in several cycles, particularly five-membered heterocyclic rings..$^{[12,13,14,15]}$ Our strategy in the CA-4 field has been focused on the replacement of the unstable Z-double bond by several linkers ${ }^{[16,17]}$ of different sizes, from which the one-atom linker was found to be the optimal length of the bridge between the two aromatic $A$ and $B$ rings. These studies have revealed novel promising classes of non-isomerizable combretastatin A-4 analogues, ${ }^{[17]}$ including 1,1-diarylethylenes $\mathbf{1},{ }^{[18,19]} \mathbf{1 , 1}$-diarylethanes $\mathbf{2}^{[20]}$ and azaisoerianin derivatives $\mathbf{3}^{[21]}$ (Figure 1). Thus, we have demonstrated that it is possible to replace the $Z-1,2$-diarylethylene scaffold of CA-4 by a 1,1diarylethylene one giving isoCA-4, a structural isomer of CA-4, with biological activities comparable to that of the natural product. $^{[18,19,22]}$ We have next showed that it is possible to reduce the double bond of isoCA-4 to furnish $( \pm)$-isoerianin 2a, ${ }^{[20]}$ which also displayed excellent anti-cancer activities comparable to that of natural erianin. ${ }^{[23]}$ Very recently, we have prepared azaisoerianin derivatives 3 and we were pleased to observe that such compounds were as potent as their $C$ congeners. ${ }^{[21]}$ The structural features of all the related compounds 1-3 are $(I)$ the conformational relationship of the $A$ and $B$ rings which must be inclined toward each other with $a$ dihedral angle ranging from $50-80^{\circ[17]}$ and (ii) the presence of the trimethoxyphenyl A-ring. This latter fragment is an essential component to induce cytotoxicity of the compounds 1-3 in addition to its crucial role in tubulin binding. ${ }^{[20,24]}$ It is interesting to note that in the isoCA4 analogues 1-3, substitution of the 3,4,5-trimethoxyphenyl A-ring with heterocyclic structures has received very little attention. ${ }^{[25,26,27]}$ 


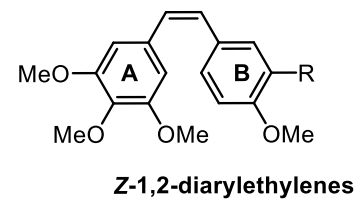

CA-4 $\mathrm{R}=\mathrm{OH}$

CA-4P $\quad \mathrm{R}=\mathrm{OPO}_{3} \mathrm{Na}_{2}$

AVE-8062 R $=\mathrm{NH}-\mathrm{Ser}, \mathrm{HC}$<smiles>COc1ccc(Nc2nc(C)nc3ccccc23)cc1</smiles>

MPC-6827<smiles>[R]c1cc(C(=C)c2ccc(OC)c(OC)c2)ccc1OC</smiles>

isocA-4 $1 \mathrm{a} \quad \mathrm{R}=\mathrm{OH}$

isoNH $\mathrm{NH}_{2} \mathrm{CA}$ 1b $\mathrm{R}=\mathrm{NH}_{2}$

isoFCA-4 1c $\mathrm{R}=\mathrm{F}$<smiles>[R]c1cc(C(C)c2cc(OC)c(OC)c(OC)c2)ccc1OC</smiles>

isoerianin $2 \mathrm{a} \quad \mathrm{R}=\mathrm{OH}$ this work

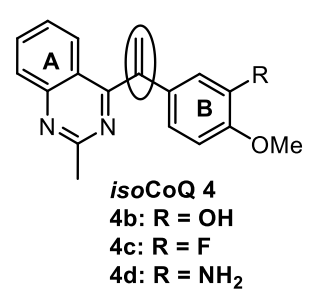<smiles>[R]c1cc(N(C)c2ccc(OC)c(OC)c2)cc(OC)c1OC</smiles>

azaisoerianin $3 a \mathrm{a}=\mathrm{OH}$

Figure 1. Representative inhibitors of tubulin polymerization and rational drug design from MPC-6827 and azaisoerianin 3 to novel 1 aryl-1-quinazoline ethylene analogues 4.

In 2007, Cail ${ }^{25,26]}$ reported the discovery of MPC-6827, containing a quinazoline nucleus, as a potent cytotoxic $\left(\mathrm{Gl}_{50}=\right.$ $6 \mathrm{nM}$ on HCT cells and others) and apoptosis small molecule $\left(E C_{50}=2 \mathrm{nM}\right)$ that prevent the microtubule formation with potency equal to that of vinblastin. Due to structural resemblances between MPC-6827 and azaisoerianin derivatives 3 , we have prepared a series of novel derivatives 4 , as isoCA-4 analogues, in which a quinazoline ring replaced the "traditional" 3,4,5-trimethoxyphenyl unit. ${ }^{[28]}$ Herein, we report the synthesis of isocombretaquinazolines 4 (isoCoQ) along with their biological properties that will allow us to conclude whether the 3,4,5-trimethoxyphenyl A-ring is as crucial as originally postulated, and about the possibility to replace it in these derivatives while maintaining an antitumor activity of first order. Our goal is the further definition of structure-activity relationships among this class of substituted quinazolines as effective agents for the treatment of solid tumors. Our initial results with 14 isocombretaquinazoline derivatives $\mathbf{4}$ are presented in this paper.

\section{Results and Discussion}

\section{Chemistry.}

The retrosynthetic analysis of the target isoCoQ 4 is outlined in Figure 2. According to path $a$, we first envisioned that quinazolines of type 4 could be prepared in a convergent manner from methylketones 6 through the palladium coupling reactions of their $\mathrm{N}$-tosylhydrazones with various aryl halides according to a recent methodology developed by Barluenga. ${ }^{[29]}$ Quinazolinemethylketones 6 should be available by the cyanation of 4-chloroquinazolines 5 followed by the addition of methylmagnesium halide on the nitrile function of $\mathbf{8}$. An alternative approach (path b), consists in the palladiumcatalyzed couplings of variously substituted- $N$-tosylhydrazones of type 7, available from their corresponding ketones, with quinazolines $\mathbf{5 a}, \mathbf{b}$ bearing on the 4-position a chlorine atom.

At the outset of this work, and according to path a (Scheme 1), we first transformed under palladium catalysis, the 4- chloroquinazoline $\mathbf{5 a}$ into 2-methylquinazoline-4-carbonitrile $\mathbf{8 a}$ using $\mathrm{Zn}(\mathrm{CN})_{2}$ as the nucleophile in a $82 \%$ yield. ${ }^{[30]}$
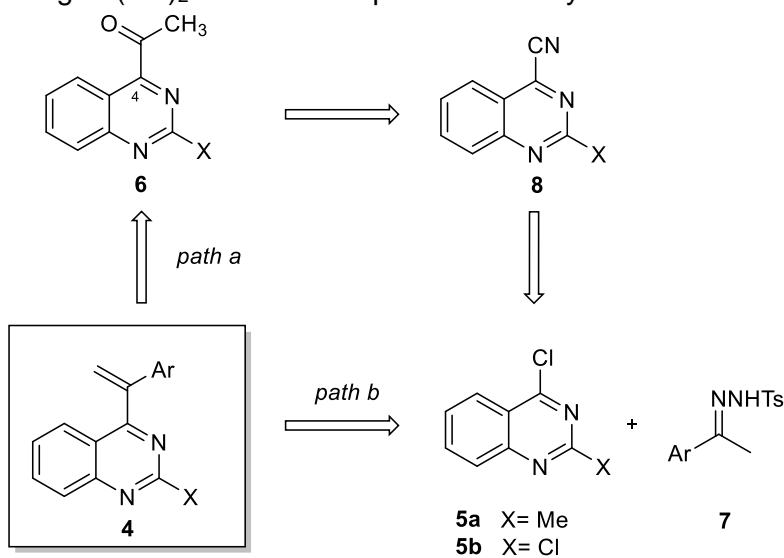

Figure 2. Retrosynthetic analysis of isoCoQ 4.

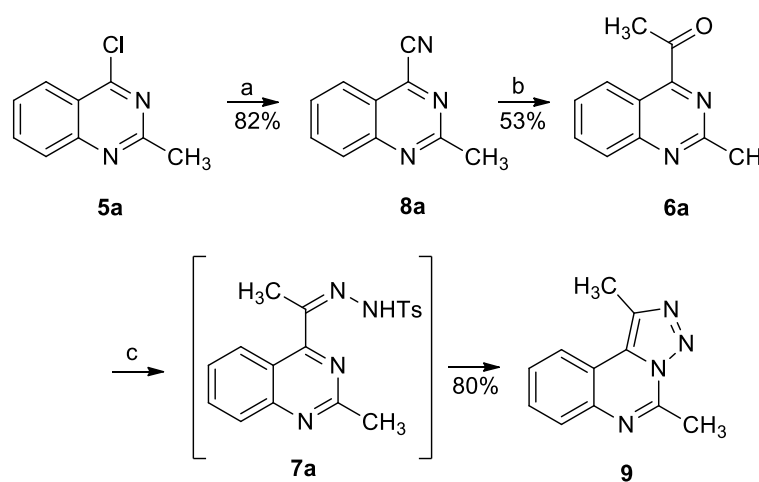

Scheme 1. Attempt to the synthesis of 7a. Reagents and conditions: a) $\mathrm{Zn}(\mathrm{CN})_{2}, \mathrm{Pd}\left(\mathrm{PPh}_{3}\right)_{4}(10 \mathrm{~mol} \%), \mathrm{DMF}, 120^{\circ} \mathrm{C}$; b) $\mathrm{CH}_{3} \mathrm{Mgl}$ (2 equiv), $\mathrm{Et}_{2} \mathrm{O},-15{ }^{\circ} \mathrm{C}$, then $\mathrm{HCl}$; c) $\mathrm{TsNHNH}_{2}$ (2 equiv), $\mathrm{EtOH}, 80^{\circ} \mathrm{C}$.

Next, reaction of $8 \mathbf{a}$ with $\mathrm{CH}_{3} \mathrm{Mgl}$ (2 equiv) at $-15{ }^{\circ} \mathrm{C}$ in $\mathrm{Et}_{2} \mathrm{O}$ furnished the methylketone $6 \mathrm{a}(53 \%)$. However, despite all our efforts, we were unable to prepare the desired tosylhydrazone 
Table 1. Synthesis of $\mathrm{N}$-tosylhydrazones 7 and isoCoQ 4a-n.

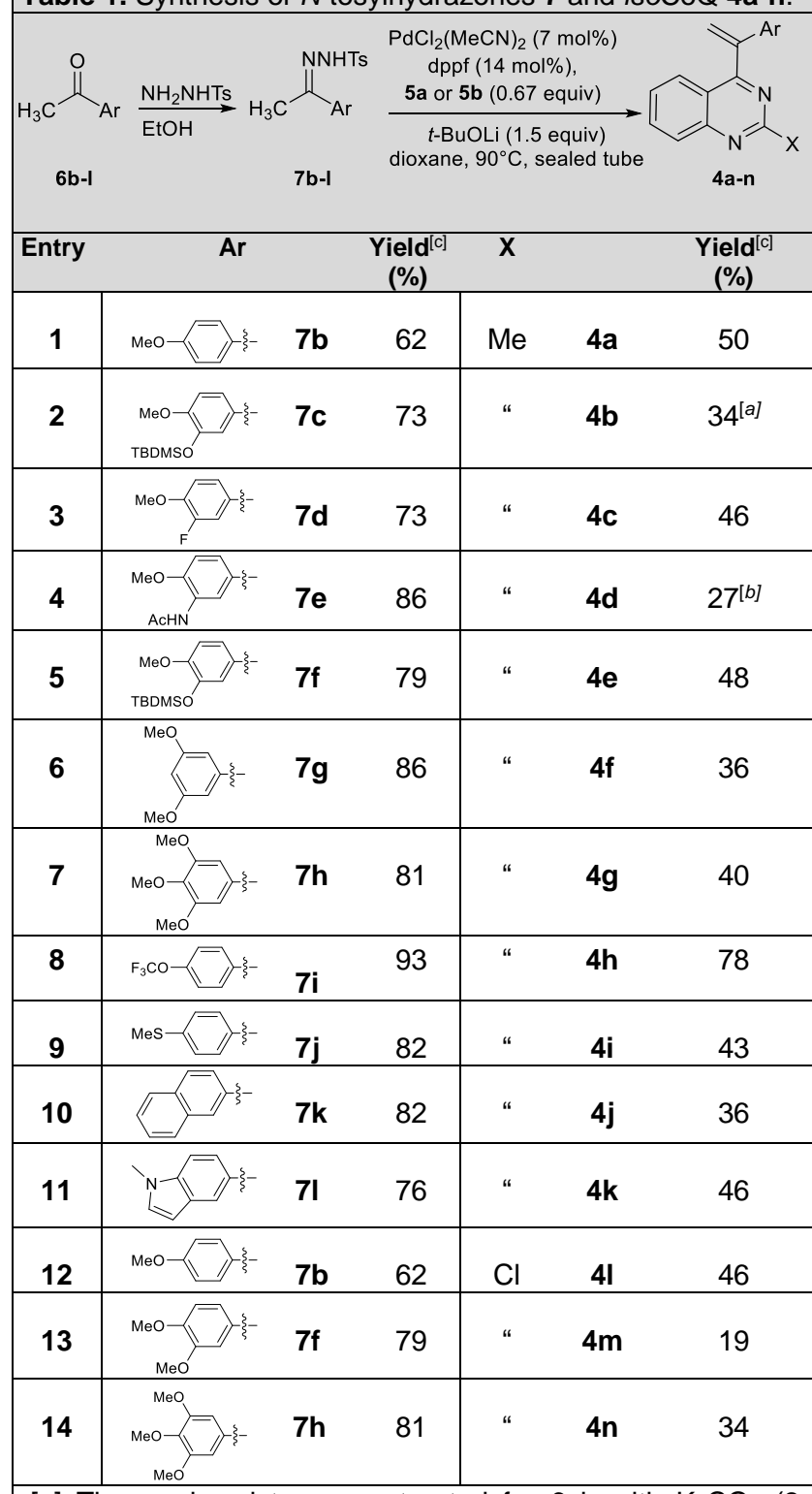

[a] The crude mixture was treated for $6 \mathrm{~h}$ with $\mathrm{K}_{2} \mathrm{CO}_{3}(2$ equiv) in $\mathrm{MeOH}$ at rt. [b] The crude mixture was treated with $\mathrm{KOH}$ (20 equiv) in $\mathrm{MeOH}$ at $100^{\circ} \mathrm{C}$ for $24 \mathrm{~h}$ in a sealed tube. [c] Yields of isolated products.

7a, useful for further coupling reactions under Pd-catalysis. Whatever the experimental conditions tested using methanol or ethanol as the solvents, by varying the amount of hydrazine, or by using with or without microwave irradiation at $80{ }^{\circ} \mathrm{C}$, hydrazine $\mathbf{7 a}$, formed in situ, rearranged to triazole $\mathbf{9}$, as it was previously reported by Reimlinger in the isoquinoline series. ${ }^{[31]}$ Facing this difficulty, the synthesis of isoCoQ 4a-n was next envisioned according to path $b$ (Figure 2) involving the Pdcatalyzed coupling of 4-chloroquinazolines $\mathbf{5 a , b}$ with several $\mathrm{N}$-tosylhydrazones $\mathbf{7 b}$-I (Table 1 ). These latter compounds were prepared from their corresponding ketones in $\mathrm{EtOH}$ with satisfactory yields ranging from 62 to $93 \%$. All $\mathrm{N}$ tosylhydrazones 7 were successfully coupled with $\mathbf{5 a}$ and $\mathbf{5 b}$ by using $\mathrm{PdCl}_{2}(\mathrm{MeCN})_{2}$ as the catalyst, 1,1'bis(diphenylphosphino)ferrocene (dppf) as the ligand, $t$-BuOLi as the base in hot dioxane in a sealed tube. ${ }^{[32]}$ All coupling yields were modest (19-78\%) but afforded sufficient quantities of isoCoQ derivatives for preliminary biological tests. For the preparation of quinazolines having a $\mathrm{OH}$ or $\mathrm{NH}_{2}$ substituent (4b and $\mathbf{4 d}$ ), their precursors hydrazones were used as silylated ether 7c or acetamide 7e, which were deprotected after the coupling step under basic conditions (entries 2 and 4). When the Pd-coupling sequence was achieved with $\mathbf{5 b}$ bearing two chlorine atoms on the $\mathrm{C} 2$ and $\mathrm{C} 4$ position of the quinazoline nucleus, the results observed in entries 12-14 clearly indicate that the $\mathrm{C} 4-\mathrm{Cl}$ bond is more reactive than the $\mathrm{C} 2-\mathrm{Cl}$ bond, which remain unchanged under our experimental conditions after a careful examination of the crude mixture.

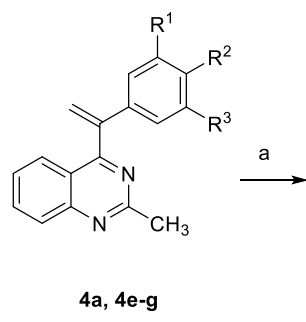<smiles>[R]c1cc(C(C)c2nc(C)nc3ccccc23)cc([R])c1[R]</smiles>

10a, $R^{1}=H, R^{2}=O M e, R^{3}=H(99 \%)$ $10 b, R^{1}=O M e, R^{2}=O M e, R^{3}=H(97 \%)$ 10c, $R^{1}=O M e, R^{2}=H, R^{3}=$ OMe $(89 \%)$ 10d, $R^{1}=O M e, R^{2}=O M e, R^{3}=$ OMe $(97 \%)$

Scheme 2. Reduction of $4 \mathrm{a}$ and $4 \mathrm{e}-\mathrm{g}$ into $10 \mathrm{a}-\mathrm{d}$. Reagents and conditions: a) $\mathrm{H}_{2}, \mathrm{Pd} / \mathrm{C}, \mathrm{EtOAc}, 20^{\circ} \mathrm{C}, 12 \mathrm{~h}$.

Finally, because the double bond present in isoCA-4 can be reduced to furnish isoerianin derivatives with no significant loss of anticancer properties, we next reduced the ethylene double bond of isoCoQ derivatives $4 \mathbf{a}$ and $4 \mathbf{e}-\mathbf{g}$ into $10 \mathrm{a}-\mathrm{d}$ with quantitative yields (Scheme 2).

\section{Biology}

\section{(A) In Vitro Cell Growth Assay}

Table 2. Cytotoxicities $\left(\mathrm{Gl}_{50}\right)$ of compounds 4 and 10 against human colon carcinoma cell line $(\mathrm{HCT} 116)^{c}$. Data are the mean of 3 experiments.

\begin{tabular}{|c|c|c|c|c|c|}
\hline Cpnd & $4 a$ & $4 b$ & $4 c$ & $4 d$ & $4 e$ \\
\hline $\begin{array}{l}\mathrm{Gl}_{50}{ }^{a} \\
(n M)\end{array}$ & $35 \pm 2$ & $6.1 \pm 0.5$ & $14.8 \pm 3.4$ & $10.1 \pm 3.2$ & $219 \pm 12$ \\
\hline Cpnd & $4 f$ & $4 g$ & $4 h$ & $4 i$ & $4 j$ \\
\hline $\begin{array}{l}\mathrm{Gl}_{50}{ }^{a} \\
(n M)\end{array}$ & $\mathrm{Na}^{\mathrm{b}}$ & $\mathrm{Na}^{\mathrm{b}}$ & $3740 \pm 230$ & $50 \pm 15$ & $138 \pm 37$ \\
\hline Cpnd & $4 k$ & 41 & $\mathrm{~m}$ & $4 n$ & $10 a$ \\
\hline $\begin{array}{l}\mathrm{Gl}_{50}{ }^{a} \\
(n M)\end{array}$ & $17.8 \pm 2.6$ & $36.7 \pm 0.75$ & $96 \pm 4$ & $\mathrm{Na}^{\mathrm{b}}$ & $146 \pm 42$ \\
\hline Cpnd & $10 \mathrm{~b}$ & $10 c$ & $10 d$ & CA-4 & isoCA- $4^{\mathrm{d}}$ \\
\hline $\begin{array}{l}\mathrm{GI}_{5_{5}}{ }^{\mathrm{a}} \\
(\mathrm{nM})\end{array}$ & $1270 \pm 700$ & $\mathrm{Na}^{\mathrm{b}}$ & $\mathrm{Na}^{\mathrm{b}}$ & $2.1 \pm 1$ & $2.4 \pm 0.5$ \\
\hline \multicolumn{6}{|c|}{$\begin{array}{l}\text { [a] A sample's concentration, which produces a } 50 \% \\
\text { reduction in cell growth. [b] Non active. [c] HCT116, colon } \\
\text { carcinoma; [d] The } \mathrm{GI}_{50} \text { values for isoCA-4 and CA-4 were } \\
\text { determined in this study. }\end{array}$} \\
\hline
\end{tabular}

All new quinazolines $\mathbf{4 a - n}$ and $\mathbf{1 0 a - d}$ were evaluated in a preliminary assay for their cytotoxic effects against human colon carcinoma (HCT116) cell line using CA-4, ${ }^{[33]}$ and isoCA-4 as reference compounds (Table 2). Seven compounds $\mathbf{4 a}, \mathbf{4 b}$, $\mathbf{4 c}, \mathbf{4 d}, \mathbf{4} \mathbf{i}, \mathbf{4 k}$ and $\mathbf{4 I}$ were found to display strong growth 
inhibitory activity against HCT116 cells with $\mathrm{Gl}_{50}$ values lower to $50 \mathrm{nM}$. As we have previously observed with other isoCA-4 analogues, ${ }^{[E r r e u r ~ ! ~ S i g n e t ~ n o n ~ d e ́ f i n i ., 21,34,35] ~ c o m p o u n d s ~} \mathbf{4 b}, \mathbf{4 c}$ and $\mathbf{4 d}$ having the greatest resemblance to isoCA-4, isoFCA-4 and iso $\mathrm{NH}_{2} \mathrm{CA}-4$, respectively, possessed the highest potency, inhibiting the growth of $\mathrm{HCT} 116$ with $\mathrm{GI}_{50}$ values ranging from 10-18 $\mathrm{nM}$. These $\mathrm{Gl}_{50}$ values are comparable to those obtained with isoCA-4 clearly indicating that it is possible to replace the 3,4,5-trimethoxyphenyl A-ring of isoCA-4 by a quinazoline ring with no significant loss of biological activity. Comparing the 4-methoxy derivative 4a with the 4-thiomethyl analogue $4 \mathbf{i}$ indicates that it is also possible to replace the 4methoxy substitutent of the B-ring with a minimal loss of activity (35 nM vs $50 \mathrm{nM}$, respectively). As it was reported in the CA-4 series, $\left[{ }^{27,36}\right]$ our findings show that a $N$-methyl indole ring could be introduced as B-ring $\left(\mathbf{4 k} ; \mathrm{Gl}_{50}=18 \mathrm{nM}\right)$ in place of the 3-hydroxy-4-methoxyphenyl ring. Replacement of the 2methyl group of quinazoline $\mathbf{4 a}$ with a chlorine atom was examined and it is interesting to note that compound $4 \mathbf{I}\left(\mathrm{Gl}_{50}=\right.$ $37 \mathrm{nM}$ ), with a chlorine atom at the $\mathrm{C}-2$ position, maintains a high cytotoxicity level as compared to $4 a\left(\mathrm{Gl}_{50}=35 \mathrm{nM}\right)$. Finally, reducing the ethylene bond of quinazolines $4 \mathrm{a}$ and $4 \mathrm{e}-$ $\mathbf{g}$ to give compounds $\mathbf{1 0 a - d}$ resulted in a nearly complete loss of activity indicating that the double bond between the quinazoline and the B-ring is critical for activity.

\section{(B) Cytotoxicity and Inhibition of Tubulin Polymerization} for Selected Compounds

Table 3. Cytotoxic activity and inhibition of tubulin polymerization of selected isoCoQ compounds 4 . Data are the mean of 3 experiments.

\begin{tabular}{|c|c|c|c|c|}
\hline \multicolumn{4}{|c|}{ Cytotoxicity $\mathrm{Gl}_{50}{ }^{\mathrm{a}}[\mathrm{nM}]$} & \multirow{2}{*}{$\begin{array}{l}\text { ITP }^{c} \\
I_{50} \\
{[\mu \mathrm{M}]}\end{array}$} \\
\hline Cpnd & НCT116 & $\mathrm{K} 562^{\mathrm{b}}$ & U87 ${ }^{b}$ & \\
\hline $4 a$ & $35 \pm 2$ & $25.1 \pm 3.8$ & $41 \pm 1.7$ & $2.1 \pm 0.3$ \\
\hline $4 b$ & $6.1 \pm 0.5$ & $6.2 \pm 0.14$ & $5.3 \pm 0.2$ & $0.6 \pm 0.1$ \\
\hline $4 c$ & $14.8 \pm 3.4$ & $31.5 \pm 1.45$ & $10.7 \pm 0.35$ & $1.0 \pm 0.15$ \\
\hline $4 d$ & $10.1 \pm 3.2$ & $9.5 \pm 0.9$ & $20.1 \pm 7.2$ & $2.3 \pm 0.5$ \\
\hline $4 i$ & $50 \pm 15$ & $40.5 \pm 1.75$ & $93 \pm 3.7$ & $2.9 \pm 0.4$ \\
\hline $4 k$ & $17.8 \pm 2.6$ & $20.7 \pm 1.5$ & $15.4 \pm 4.1$ & $1.6 \pm 0.3$ \\
\hline 41 & $36.7 \pm 0.75$ & $22.2 \pm 3.0$ & $41 \pm 1.7$ & $1.9 \pm 0.15$ \\
\hline IsoCA-4 ${ }^{\mathrm{d}}$ & $2.4 \pm 0.5$ & $4.98 \pm 1.35$ & $6.8 \pm 0.1$ & $1.0 \pm 0.1$ \\
\hline
\end{tabular}

[a] $\mathrm{Gl}_{50}$ is the concentration of compound needed to reduce cell growth by $50 \%$ following $72 \mathrm{~h}$ cell treatment with the tested drug (average of three experiments). [b] HCT116, colon carcinoma; K562, myelogenous leukaemia; U87, glioblastoma. [c] ITP, Inhibition of Tubulin Polymerization; $\mathrm{IC}_{50}$ is the concentration of compound required to inhibit $50 \%$ of the rate of microtubule assembly (average of three experiments). [d] The $\mathrm{GI}_{50}$ and $\mathrm{IC}_{50}$ values (cytotoxicity and ITP, respectively) for isoCA-4 was determined in this study.

We next have investigated the effect of the most bioactive derivatives (4a-d, $\mathbf{4 i}, \mathbf{4 k}, \mathbf{I})$ having a low $\mathrm{Gl}_{50}$ value on HCT116 cells, on the proliferation of two other tumor cell lines, myelogenous leukemia (K562) and human primary glioblastoma (U87). The results depicted in Table 3 revealed that all selected isoCoQ compounds $\mathbf{4}$ which retain a high level
Figure 4. Apoptotic effects of $\mathbf{4 b}$ (green), 4c (brown) and $\mathbf{4 d}$ (purple) in U87 cells. The results are expressed in the percentage of apoptotic cells detected following $24 \mathrm{~h}$ of treatment with $\mathbf{4 b}-\mathbf{d}$ at $25 \mathrm{nM}$. Data are the mean of 3 experiments; errors bars represent the SD.

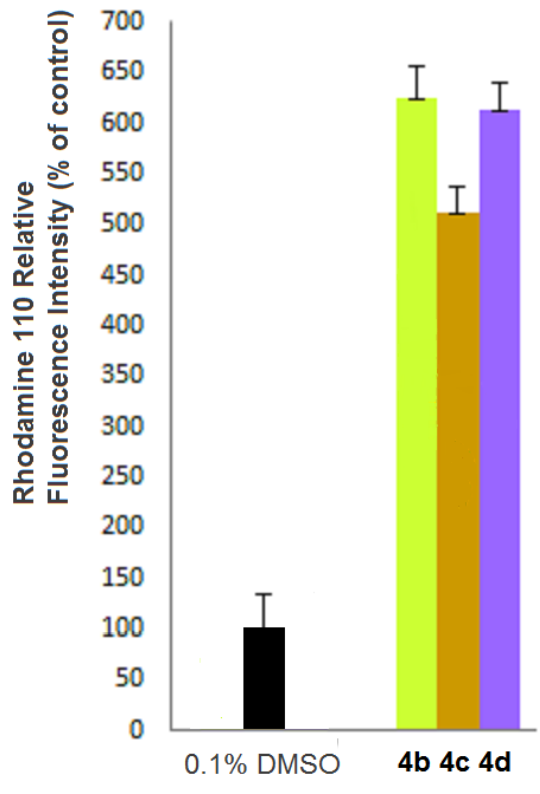

of cytotoxicity against HCT116 also displayed a nanomolar level of cytotoxicity regardless of the origin of the tumor cells. For example, the phenolic derivative $\mathbf{4 b}$, having the greatest resemblance with isoCA-4 and CA-4 remained the most cytotoxic agent against $\mathrm{K} 562$ and $\mathrm{U} 87$ with $\mathrm{Gl}_{50}$ values inferior to $10 \mathrm{nM}(5-6 \mathrm{nM})$. As it was previously described, ${ }^{\text {[Erreur ! Signet }}$ non défini., ${ }^{37]}$ various modifications are possible on the B-ring of isocombretaquinazolines, as replacing the $3^{\prime} \mathrm{OH}$ group by a hydrogen, a fluorine atom or a $\mathrm{NH}_{2}$ function, yielding potent compounds. To confirm that the antiproliferative activities of these derivatives, like those of CA-4 and isoCA-4, were related to an interaction with the microtubule system, all selected isoCoQ 4 having low $\mathrm{IC}_{50}$ values against various cancer cells were evaluated for their inhibitory effect on tubulin assembly. As expected, all tested compounds $\mathbf{4}$ strongly inhibited tubulin assembly with comparable $\mathrm{IC}_{50}$ values of 0.6-2.9 $\mu \mathrm{M}$. Again, the most cytotoxic agent $\mathbf{4} \mathbf{b}$ is also the most efficient derivative to inhibit tubulin polymerization with an $\mathrm{IC}_{50}$ value of $0.6 \mu \mathrm{M}$, two times lower than that of isoCA-4 $\left(\mathrm{IC}_{50}=1.0 \mu \mathrm{M}\right)$.

\section{(C) Cell Cycle Analysis and Apoptosis}

Because molecules exhibiting activity on tubulin should cause the alteration of cell cycle parameters leading to a preferential $\mathrm{G}_{2} / \mathrm{M}$ arrest, ${ }^{[38]}$ we next investigated the effects of the most potent isocombretaquinazolines $\mathbf{4 b} \mathbf{b} \mathbf{d}$ on the cell cycle. Cancer

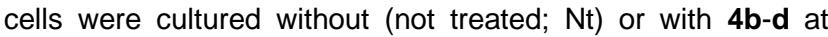
increasing concentrations and the cell cycle distribution was analyzed by flow cytometry after $24 \mathrm{~h}$ of treatment using the standard propidium iodide procedure. Cell cycle analysis on HCT116 cells (Figure 3 ) showed that similarly $\mathbf{4 b}, \mathbf{4 c}$ and $\mathbf{4 d}$ caused a massive cell accumulation in the $G_{2} / M$ phase of the 
Figure 3. Effects of $\mathbf{4 b}$ (left), $\mathbf{4 c}$ (middle) and $\mathbf{4 d}$ (right) at increasing concentrations on cell cycle distribution in HCT116 cell lines (Human Colon Carcinoma). Nt: no treatment.

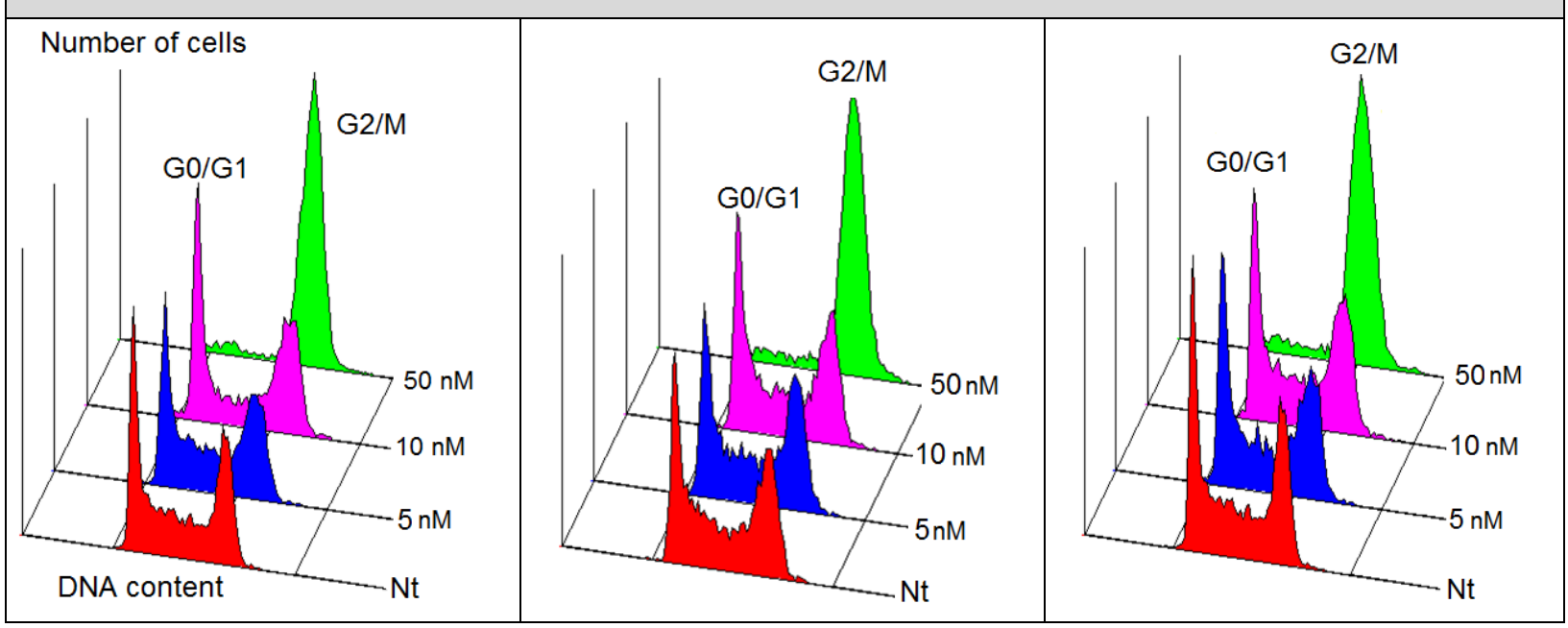

cell cycle at the concentration of $50 \mathrm{nM}$. We examined whether the very bioactive quinazoline derivatives $\mathbf{4 b}$ - $\mathbf{d}$, in addition to arresting mitosis in the $\mathrm{G}_{2} / \mathrm{M}$ phase, also triggered cell death in U87 cells using caspases 3 and 7 standard assays. ${ }^{[39]}$ U87 cells were incubated for $24 \mathrm{~h}$ with $\mathbf{4 b}, \mathbf{4 c}$ and $\mathbf{4 d}$ at low concentrations and the activity of caspases was measured by monitoring the cleavage of the fluorogenic substrate Z-DEVDR110 in U87 cells. As observed in Figure 4, 4b, 4c and 4d can strongly induce caspases 3 and 7 at the concentration of 25 $\mathrm{nM}$.

\section{(D) Effects of isoCoQ 4d on HUVEC Organization}

Figure 5. In vitro effects of $\mathbf{4 d}$ on HUVEC cells (Human Umbilical Vein Endothelial Cells) at a concentration of $50 \mathrm{nM}$ on new formed vessels after $1 \mathrm{~h}$ of treatment.

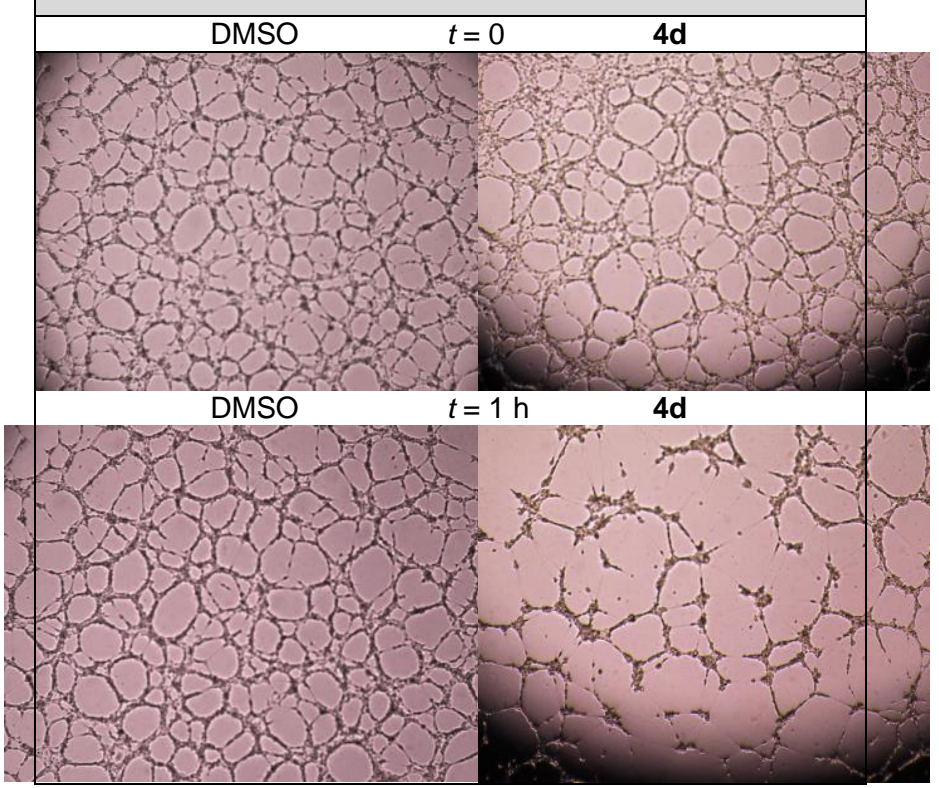

The isocombretaquinazoline $\mathbf{4 d}$ bearing a $\mathrm{NH}_{2}$ group on $\mathrm{C}^{\prime}$ position was evaluated for its ability to disrupt a network of capillary-like structures formed by human umbilical vein endothelial cells (HUVECs) on Matrigel. On this matrix, HUVECs spontaneously align forming a network of interconnecting cords, mimicking the breakable tumor vasculature. After a short reaction time of $1 \mathrm{~h}, \mathbf{4 d}$ disrupts the vessels-like structure and the entire integrity of the network at a concentration of $50 \mathrm{nM}$ (Figure 5). One note that at this concentration of $50 \mathrm{nM}$ and after one hour of treatment, $\mathbf{4 d}$ was not cytotoxic against HUVECs (data not shown), indicating that the strong observed disrupting effects are only due to the possible antivascular properties of $\mathbf{4 d}$.

\section{(E) Docking Study}

Docking experiments with $\mathbf{4 b} \mathbf{b} \mathbf{d}$ and indolo-derivative $\mathbf{4 k}$ showed that these bioactive isocombretaquinazoline compounds could adopt a similar conformation within the colchicine-binding site in tubulin (Figure 6). In this hypothetical common binding mode, the methylquinazoline ring would occupy one of the major lipophilic pockets belonging to the $\beta$ subunit (which is also supposed to accomodate A-ring from isoCA-4). Within this pocket, $\mathrm{N}-1$ nitrogen atom in the heteroaromatic system would be in a close enough proximity of the $\mathrm{SH}$ group belonging to Cys $\beta 241$ to permit the establishment of a strong interaction with this residue. Study of the variations in the B-ring suggested that binding of derivatives $\mathbf{4 b}$ and $\mathbf{4 d}$ might be reinforced by the formation of a hydrogen bond between their $\mathrm{O}-\mathrm{H}$ or $\mathrm{N}-\mathrm{H}$ moiety (respectively) and the backbone oxygen belonging to Thr $\alpha 179$.

\section{Conclusion}

We have designed, synthesized and evaluated a series of isocombretaquinazolines devoid of the 3,4,5-trimethoxyphenyl ring. Many of these original compounds displayed a nanomolar level of cytotoxicity against various cancer cell lines and inhibited tubulin polymerization at a micro or submicromolar level. Our best derivatives arrested the cellular cycle in the G2/M phase at a low concentration of $50 \mathrm{nM}$ in HCT116 cells. Moreover, preliminary in vitro results reveal that $\mathbf{4 d}$ disrupt vessels-like structure on Matrigel and is a potent vascular disrupting agent. 


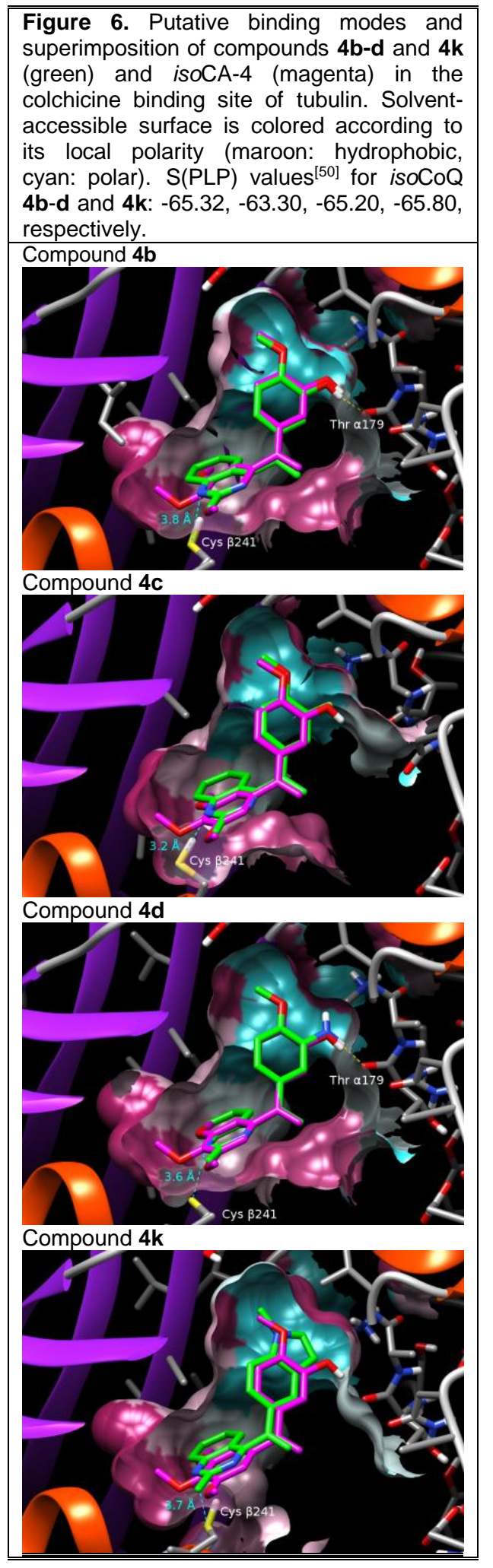

For the first time, all of these results reveal that the replacement of the 3,4,5-trimethoxyphenyl ring by a quinazoline nucleus is possible in the isoCA-4 series. Modification of heterocyclic systems is in progress in our lab and will be published later.

\section{Experimental Section}

\section{Chemistry}

General considerations
NMR spectra were performed on a Bruker AVANCE $300\left({ }^{1} \mathrm{H}, 300\right.$ $\left.\mathrm{MHz} ;{ }^{13} \mathrm{C}, 75 \mathrm{MHz}\right)$ or Bruker AVANCE $400\left({ }^{1} \mathrm{H}, 400 \mathrm{MHz} ;{ }^{13} \mathrm{C}, 100\right.$ $\mathrm{MHz}$ ). Unless otherwise stated, $\mathrm{CDCl}_{3}$ was used as solvent. Chemical shifts $\delta$ are in ppm, and the following abbreviations are used: singlet (s), doublet $(\mathrm{d})$, triplet $(\mathrm{t})$, multiplet $(\mathrm{m})$, broad singlet (brs). Mass spectra were obtained using a Bruker Esquire electrospray ionization apparatus. High resolution mass spectra were recorded on a MicrotofQ Bruker Daltonics. Thin-layer chromatography was performed on silica gel 60 plates with a fluorescent indicator and visualized under a UVP Mineralight UVGL-58 lamp (254 $\mathrm{nm})$ and with a 7\% solution of phosphomolybdic acid in ethanol. Flash chromatography was performed using silica gel 60 (40-63 $\mu \mathrm{m}, 230-400$ mesh ASTM) at medium pressure (200 mbar). All solvents were distilled and stored over $4 \AA$ molecular sieves before use. All reagents were obtained from commercial suppliers unless otherwise stated. Organic extracts were, in general, dried over magnesium sulphate $\left(\mathrm{MgSO}_{4}\right)$ or sodium sulphate $\left(\mathrm{Na}_{2} \mathrm{SO}_{4}\right)$.

\section{Procedure for the synthesis of 1-(2-Methylquinazolin-4- yl)ethanone $6 a$}

A solution of methylmagnesium iodide solution in $\mathrm{Et}_{2} \mathrm{O}$ [3M] (3.42 $\mathrm{mL}, 10.28 \mathrm{mmol}$ ) was added to a stirred solution of 4-cyano, 2methylquinazoline $8(870 \mathrm{mg}, 5.14 \mathrm{mmol})$ in $\mathrm{Et}_{2} \mathrm{O}(20 \mathrm{~mL})$ at -15 ${ }^{\circ} \mathrm{C}$ for $1 \mathrm{~h}$. Then, the reaction mixture was allowed to warm to room temperature. The reaction mixture was acidified with $\mathrm{HCl} 2 \mathrm{~N}(8$ $\mathrm{mL})$ and the product was extracted with diethyl ether $(2 \times 15 \mathrm{~mL})$. The organic layers were combined and washed with aqueous $\mathrm{NaHCO}_{3}$ and brine. After concentration, the reaction mixture was purified by silica gel chromatography to afford $\mathbf{6 a}$ as a pale yellow colored liquid (53\% yield). Rf 0.6 (Cyclohexane/EtOAc, 7/3). IR (neat, $\mathrm{cm}^{-1}$ ): 2927, 1696, 1613, 1557, 1484, 1358, 1144. ${ }^{1} \mathrm{H}$ NMR $\left(300 \mathrm{MHz}, \mathrm{CDCl}_{3}\right): 8.67$ (d, $\left.1 \mathrm{H}, J=8.5 \mathrm{~Hz}\right), 7.99$ (d, $1 \mathrm{H}, J=8.5$ $\mathrm{Hz}$ ), 7.88 (ddd, $1 \mathrm{H}, J=8.5 \mathrm{~Hz}, J=6.9 \mathrm{~Hz}, J=1.4 \mathrm{~Hz}$ ), 7.63 (ddd, $1 \mathrm{H}, J=8.3 \mathrm{~Hz}, J=6.9 \mathrm{~Hz}, J=1.2 \mathrm{~Hz}$ ), $2.94(\mathrm{~s}, 3 \mathrm{H}), 2.83(\mathrm{~s}, 3 \mathrm{H})$. ${ }^{13} \mathrm{C}$ NMR $\left(75 \mathrm{MHz}, \mathrm{CDCl}_{3}\right): 202.3,163.6,159.6,152.7,134.2$, 128.5, 128.3, 126.5, 118.8, 28.2, 26.4. $\mathrm{m} / z \mathrm{MS}\left(\mathrm{APCl}^{+}\right): 187(\mathrm{M}+$ $H)^{+}$. HRMS $\left(E S I^{+}\right): m / z$ calculated for $\mathrm{C}_{11} \mathrm{H}_{11} \mathrm{~N}_{2} \mathrm{O}[\mathrm{M}+\mathrm{H}]^{+}$187.0866; found 187.0877 .

\section{Procedure for the synthesis of 1,5-Dimethyl-[1,2,3]triazolo[1,5- c]quinazoline 9}

To a solution of $6 \mathbf{a}(0.537 \mathrm{mmol})$ in $\mathrm{EtOH}(4 \mathrm{~mL})$ was added $p$ toluenesulfonylhydrazide $(200 \mathrm{mg}, 1.07 \mathrm{mmol}$ ). The resulting solution was stirred at $80^{\circ} \mathrm{C}$ for $30 \mathrm{~min}$. After concentration, the reaction mixture was purified by silica gel chromatography to afford the compound 9 as a white solid $\left(80 \%\right.$ yield). M.p.: $158.2^{\circ} \mathrm{C}$. Rf 0.4 (Cyclohexane/EtOAc, 7/3). IR (neat, $\mathrm{cm}^{-1}$ ): 1631, 1475, 1430, 1390, 1361, 1024. ${ }^{1} \mathrm{H}$ NMR $\left(300 \mathrm{MHz}, \mathrm{CDCl}_{3}\right): 8.09$ (dd, $1 \mathrm{H}, J=$ $7.8 \mathrm{~Hz}, J=1.4 \mathrm{~Hz}$ ), $7.93(\mathrm{dd}, 1 \mathrm{H}, J=8.0 \mathrm{~Hz}, J=1.1 \mathrm{~Hz}), 7.70-7.58$ $(\mathrm{m}, 2 \mathrm{H}), 3.08$ (s, 3H), $2.86(\mathrm{~s}, 3 \mathrm{H}) \cdot{ }^{13} \mathrm{C}$ NMR $\left(75 \mathrm{MHz}, \mathrm{CDCl}_{3}\right)$ : $146.1,140.0,136.9,130.1,129.0,128.4,128.3,122.8,119.2$, 19.9, 12.8. $\mathrm{m} / \mathrm{z} \mathrm{MS}(\mathrm{APCl}+): 199(\mathrm{M}+\mathrm{H})^{+}$.

\section{General procedure for the synthesis of $N$-tosylhydrazones $7 \mathrm{~b}$-i}

To a solution of ketones $6 \mathbf{b}-\mathbf{i}(1.75 \mathrm{mmol})$ in $\mathrm{EtOH}(20 \mathrm{~mL})$ was added $p$-toluenesulfonylhydrazide $(1.75 \mathrm{mmol})$ and the mixture 
was stirred at reflux for 6 h. After cooling, the resulting $N$ tosylhydrazone was filtered and washed with $\mathrm{Et}_{2} \mathrm{O}$.

$N$-(1-(3-((tert-Butyldimethylsilyl)oxy)-4-methoxyphenyl)ethylidene)4-methylbenzenesulfonohydrazide 7c

$73 \%$ yield, white solid, Mp.: $171.3{ }^{\circ} \mathrm{C}$. $\quad$ TLC: Rf 0.4 (Cyclohexane/EtOAc, 7/3). IR (neat, $\mathrm{cm}^{-1}$ ): 3231, 1598, 1507, 1423, 1305, 1270, 1168. ${ }^{1} \mathrm{H}$ NMR $\left(300 \mathrm{MHz}, \mathrm{CD}_{3} \mathrm{COCD}_{3}\right): 9.17$ (brs, $1 \mathrm{H}), 7.87$ (d, 2H, J = 8.3 Hz), 7.38 (d, 2H, $J=8.0 \mathrm{~Hz}), 7.32$ (d, $1 \mathrm{H}, J=2.2 \mathrm{~Hz}$ ), 7.25 (dd, $1 \mathrm{H}, J=8.5 \mathrm{~Hz}, J=2.2 \mathrm{~Hz}$ ), 6.92 (d, $1 \mathrm{H}, J=8.5 \mathrm{~Hz}$ ), $3.83(\mathrm{~s}, 3 \mathrm{H}), 2.40(\mathrm{~s}, 3 \mathrm{H}), 2.05$ (s, 3H), 1.02 (s, $9 \mathrm{H}), 0.17$ (s, 6H). ${ }^{13} \mathrm{C}$ NMR (75 MHz, $\left.\mathrm{CD}_{3} \mathrm{COCD}_{3}\right): 153.6,153.3$, 145.6, 144.4, 137.7, 131.5, 130.1 (2C), 128.9 (2C), 121.3, 119.0, 112.2, 55.8, 26.3 (3C), 21.5, 19.0, 13.7, -4.41 (2C). $\mathrm{m} / z \mathrm{MS}\left(\mathrm{ESI}^{+}\right)$: $449(\mathrm{M}+\mathrm{H})^{+}$. HRMS $\left(E S I^{+}\right): m / z$ calculated for $\mathrm{C}_{22} \mathrm{H}_{32} \mathrm{~N}_{2} \mathrm{NaO}_{4} \mathrm{SSi}$ $[\mathrm{M}+\mathrm{Na}]^{+} 471.1744$; found 471.1757

$N$-(1-(3-Fluoro-4-methoxyphenyl)ethylidene)-4-methylbenzene sulfonohydrazide $7 \mathrm{~d}$

73\% yield, white solid, M.p.: $200.1{ }^{\circ} \mathrm{C}$. TLC: Rf 0.2 (Cyclohexane/EtOAc, 7/3). IR (neat, $\mathrm{cm}^{-1}$ ): 3029, 1510, 1432, 1309, 1272, 1164. ${ }^{1} \mathrm{H}$ NMR (300 MHz, $\left.\mathrm{CD}_{3} \mathrm{COCD}_{3}\right)$ : 7.88-7.76 (m, $3 \mathrm{H}), 7.69(\mathrm{~d}, 1 \mathrm{H}, J=12.2 \mathrm{~Hz}), 7.36(\mathrm{~d}, 2 \mathrm{H}, J=7.9 \mathrm{~Hz}), 7.23(\mathrm{t}, 1 \mathrm{H}$, $J=8.5 \mathrm{~Hz}$ ), $3.97(\mathrm{~s}, 3 \mathrm{H}), 2.53(\mathrm{~s}, 3 \mathrm{H}), 2.40(\mathrm{~s}, 3 \mathrm{H}), \mathrm{NH}$ not seen. ${ }^{13} \mathrm{C}$ NMR $\left(75 \mathrm{MHz}, \mathrm{CD}_{3} \mathrm{COCD}_{3}\right): 154.3,151.0,144.2(2 \mathrm{C}), 137.7$, 131.5, 130.0 (2C), 128.8 (2C), 126.8, 116.0 (d, 1C, $J=18.8 \mathrm{~Hz}$ ), 113.7, 56.7, 26.4, 21.4. ${ }^{19} \mathrm{~F}$ NMR $\left(188, \mathrm{CDCl}_{3}\right):-134.6 \mathrm{~m} / \mathrm{z} \mathrm{MS}$ $\left(\mathrm{ESI}^{+}\right): 359(\mathrm{M}+\mathrm{Na})^{+}$. HRMS $\left(\mathrm{ESI}^{+}\right): \mathrm{m} / \mathrm{z}$ calculated for $\mathrm{C}_{16} \mathrm{H}_{17} \mathrm{FN}_{2} \mathrm{NaO}_{3} \mathrm{~S}[\mathrm{M}+\mathrm{Na}]^{+}$359.0836; found 359.0854 .

N-(2-Methoxy-5-(1-(2-tosylhydrazono)ethyl)phenyl)acetamide 7e

$86 \%$ yield, white solid, M.p.: $150.6 \quad{ }^{\circ} \mathrm{C}$. TLC: Rf 0.7 (Cyclohexane/EtOAc, 3/7). IR (neat, $\mathrm{cm}^{-1}$ ): 3179, 1692, 1583, 1536, 1486, 1423, 1325. ${ }^{1} \mathrm{H}$ NMR (300 MHz, DMSO): 10.27 (brs, $1 \mathrm{H}$ ), 9.12 (brs, $1 \mathrm{H}$ ), 8.34 (s, 1H), $7.82(\mathrm{~d}, 2 \mathrm{H}, J=8.3 \mathrm{~Hz}$ ), 7.38 (d, $2 \mathrm{H}, J=8.0 \mathrm{~Hz}$ ), 7.31 (dd, $1 \mathrm{H}, J=8.6 \mathrm{~Hz}, J=2.2 \mathrm{~Hz}), 6.99(\mathrm{~d}, 1 \mathrm{H}$, $J=8.7 \mathrm{~Hz}$ ), $3.83(\mathrm{~s}, 3 \mathrm{H}), 2.36(\mathrm{~s}, 3 \mathrm{H}), 2.09(\mathrm{~s}, 6 \mathrm{H}) .{ }^{13} \mathrm{C}$ NMR $(75$ $\mathrm{MHz}, \mathrm{DMSO}): 168.5,152.9,150.6,143.1,136.2,129.6,129.3$ (2C), 127.7 (2C), 127.2, 122.3, 119.7, 110.5, 55.8, 23.9, 21.0, 14.0. $\mathrm{m} / z \mathrm{MS}\left(\mathrm{ESI}^{+}\right): 376(\mathrm{M}+\mathrm{H})^{+}, 398(\mathrm{M}+\mathrm{Na})^{+}$. HRMS $\left(\mathrm{ESI}^{+}\right)$: $\mathrm{m} / \mathrm{z}$ calculated for $\mathrm{C}_{18} \mathrm{H}_{21} \mathrm{~N}_{3} \mathrm{NaO}_{4} \mathrm{~S}[\mathrm{M}+\mathrm{Na}]^{+}$398.1145; found 398.1150 .

$N$-(1-(3,4-Dimethoxyphenyl)ethylidene)-4-methylbenzene sulfonohydrazide $7 f$

79\% yield, white solid, M.p.: $177.4{ }^{\circ} \mathrm{C}$. TLC: Rf 0.5 (Cyclohexane/EtOAc, 7/3). IR (neat, $\mathrm{cm}^{-1}$ ): 3210, 2013, 1333, 1309, 1165, 1151. ${ }^{1} \mathrm{H}$ NMR (300 MHz, DMSO): 10.3 (brs, $1 \mathrm{H}$ ), 7.83 $(\mathrm{d}, 2 \mathrm{H}, J=8.3 \mathrm{~Hz}), 7.41(\mathrm{~d}, 2 \mathrm{H}, J=8.0 \mathrm{~Hz}), 7.17-7.14(\mathrm{~m}, 2 \mathrm{H})$, $6.92(\mathrm{~d}, 1 \mathrm{H}, J=8.3 \mathrm{~Hz}), 3.75(\mathrm{~s}, 3 \mathrm{H}), 3.74(\mathrm{~s}, 3 \mathrm{H}), 2.37(\mathrm{~s}, 3 \mathrm{H})$, 2.13 (s, 3H). ${ }^{13} \mathrm{C}$ NMR (75 MHz, DMSO): 153.2, 150.1, 148.4, 143.3, 136.1, 130.0, 129.3 (2C), 127.8 (2C), 119.3, 111.0, 108.7, $55.5,55.3,21.0,14.0 . \mathrm{m} / \mathrm{z} \mathrm{MS}(\mathrm{ESI}+): 371(\mathrm{M}+\mathrm{Na})^{+}$. HRMS $\left(E S I^{+}\right): m / z$ calculated for $\mathrm{C}_{17} \mathrm{H}_{20} \mathrm{~N}_{2} \mathrm{NaO}_{4} \mathrm{~S}[\mathrm{M}+\mathrm{Na}]^{+} 371.1036$; found 371.1050 .

\section{4-Methyl- $N$-(1-(4-(trifluoromethoxy)phenyl)ethylidene)benzene sulfonohydrazide $7 \mathbf{i}$}

93\% yield, white solid, M.p.: $131.1{ }^{\circ} \mathrm{C}$. TLC: Rf 0.3 (Cyclohexane/EtOAc, 7/3). IR (neat, $\mathrm{cm}^{-1}$ ): 3219, 1597, 1509,
1339, 1315, 1258, 1161. ${ }^{1} \mathrm{H}$ NMR $\left(300 \mathrm{MHz}, \mathrm{CDCl}_{3}\right): 8.38$ (brs, $1 \mathrm{H}), 7.93(\mathrm{~d}, 2 \mathrm{H}, J=8.3 \mathrm{~Hz}), 7.66(\mathrm{~d}, 2 \mathrm{H}, J=8.9 \mathrm{~Hz}), 7.32(\mathrm{~d}, 2 \mathrm{H}$, $J=8.0 \mathrm{~Hz}), 7.16(\mathrm{~d}, 2 \mathrm{H}, J=8.1 \mathrm{~Hz}), 2.41(\mathrm{~s}, 3 \mathrm{H}), 2.17(\mathrm{~s}, 3 \mathrm{H}) .{ }^{13} \mathrm{C}$ NMR $\left(75 \mathrm{MHz}, \mathrm{CDCl}_{3}\right): 151,3,150.2,144.4,136.0,135.4,129.8$ (2C), 128.2 (2C), 127.9 (2C), 120.6 (2C), 120.5 (q, J = 257.6 Hz), 21.7, 13.6. ${ }^{19} \mathrm{~F} \mathrm{NMR}\left(188 \mathrm{MHz}, \mathrm{CDCl}_{3}\right):-58.16$. HRMS $\left(\mathrm{ESI}^{+}\right): \mathrm{m} / \mathrm{z}$ calculated for $\mathrm{C}_{16} \mathrm{H}_{15} \mathrm{~F}_{3} \mathrm{~N}_{2} \mathrm{NaO}_{3} \mathrm{~S} \quad[\mathrm{M}+\mathrm{Na}]^{+}$395.0648; found 395.0657 .

\section{4-Methyl- $N$-(1-(4-(methylthio)phenyl)ethylidene)benzene sulfonohydrazide $7 \mathbf{j}$}

$82 \%$ yield, white solid (unstable product, M.p.: $160.9{ }^{\circ} \mathrm{C}$. TLC: Rf 0.4 (Cyclohexane/EtOAc, 7/3). IR (neat, cm-1): 1590, 1399, 1187, 1165, 1079, 1044. 1H NMR (300 MHz, $\left.\mathrm{CD}_{3} \mathrm{COCD}_{3}\right): 9.29$ (brs, $1 \mathrm{H}), 7.87(\mathrm{~d}, 2 \mathrm{H}, J=8.3 \mathrm{~Hz}), 7.66(\mathrm{~d}, 2 \mathrm{H}, J=8.6 \mathrm{~Hz}), 7.38(\mathrm{~d}, 2 \mathrm{H}$, $J=8.2 \mathrm{~Hz}$ ), $7.23(\mathrm{~d}, 2 \mathrm{H}, J=8.6 \mathrm{~Hz}), 2.49(\mathrm{~s}, 3 \mathrm{H}), 2.38(\mathrm{~s}, 3 \mathrm{H})$, $2.22(\mathrm{~s}, 3 \mathrm{H}) .{ }^{13} \mathrm{C}$ NMR $\left(75 \mathrm{MHz}, \mathrm{CD}_{3} \mathrm{COCD}_{3}\right): 153.2,144.5,141.5$, 137.6, 135.1, $130.2(2 \mathrm{C}), 128.8(2 \mathrm{C}), 127.4(2 \mathrm{C}), 126.3(2 \mathrm{C}), 21.4$, 15.0, 14.6. $\mathrm{m} / \mathrm{z} \mathrm{MS}(\mathrm{ESI}+): 335(\mathrm{M}+\mathrm{H})+, 357(\mathrm{M}+\mathrm{Na})^{+}$. HRMS $\left(\mathrm{ESI}^{+}\right): \mathrm{m} / \mathrm{z}$ calculated for $\mathrm{C}_{16} \mathrm{H}_{19} \mathrm{~N}_{2} \mathrm{O}_{2} \mathrm{~S}_{2}[\mathrm{M}+\mathrm{Na}]^{+} 335.0882$; found 335.0888 .

\section{4-Methyl- $N$-(1-(naphthalen-2-yl)ethylidene)benzene sulfonohydrazide $7 \mathbf{k}$}

82\% yield, white solid, M.p.: $167.1 \quad{ }^{\circ} \mathrm{C}$. TLC: $\mathrm{Rf} 0.4$ (Cyclohexane/EtOAc, 7/3). IR (neat, $\mathrm{cm}^{-1}$ ): 3027, 1596, 1406, 1332, 1163. ${ }^{1} \mathrm{H}$ NMR (300 MHz, $\left.\mathrm{CD}_{3} \mathrm{COCD}_{3}\right): 9.44$ (brs, $\left.1 \mathrm{H}\right), 8.16$ (s, $1 \mathrm{H}), 8.01(\mathrm{dd}, 1 \mathrm{H}, J=8.8 \mathrm{~Hz}, J=1.8 \mathrm{~Hz}), 7.94-7.84(\mathrm{~m}, 5 \mathrm{H})$, 7.54-7.48 (m, 2H), $7.40(\mathrm{~d}, 2 \mathrm{H}, J=8.0 \mathrm{~Hz}), 2.37(\mathrm{~s}, 6 \mathrm{H}) .{ }^{13} \mathrm{C} \mathrm{NMR}$ $\left(75 \mathrm{MHz}, \mathrm{CD}_{3} \mathrm{COCD}_{3}\right)$ : 153.4, 144.6, 137.7, 136.2, 134.8, 134.1, 130.3 (2C), 129.5, 129.0 (2C), 128.7, 128.5, 127.7, 127.3, 127.2, 124.4, 21.5, 13.8. $\mathrm{m} / \mathrm{z} \mathrm{MS}(\mathrm{ESI}+): 339(\mathrm{M}+\mathrm{H})^{+}$. HRMS $\left(\mathrm{ESI}^{+}\right): \mathrm{m} / \mathrm{z}$ calculated for $\mathrm{C}_{19} \mathrm{H}_{18} \mathrm{~N}_{2} \mathrm{NaO}_{2} \mathrm{~S}[\mathrm{M}+\mathrm{Na}]^{+} 361.0981$; found 361.0979 .

\section{4-Methyl- $N$-(1-(1-methyl-1H-indol-5-yl)ethylidene)benzene sulfonohydrazide $7 \mathbf{I}$}

$76 \%$ yield, white solid, M.p.: $189.5{ }^{\circ} \mathrm{C}$. TLC: Rf 0.2 (Cyclohexane/EtOAc, 7/3). IR (neat, $\mathrm{cm}^{-1}$ ): 1391, 1331, 1308, 1248, 1164. ${ }^{1} \mathrm{H}$ NMR (300 MHz, DMSO): 10.24 (brs, $\left.1 \mathrm{H}\right), 7.87-$ $7.80(\mathrm{~m}, 3 \mathrm{H}), 7.53$ (dd, $1 \mathrm{H}, J=8.7 \mathrm{~Hz}, J=1.6 \mathrm{~Hz}), 7.42-7.38(\mathrm{~m}$, $3 \mathrm{H}), 7.32(\mathrm{~d}, 1 \mathrm{H}, J=3.0 \mathrm{~Hz}), 6.45(\mathrm{~d}, 1 \mathrm{H}, J=2.9 \mathrm{~Hz}), 3.78(\mathrm{~s}, 3 \mathrm{H})$, 2.37 (s, 3H), 2.22 (s, 3H). ${ }^{13} \mathrm{C}$ NMR (75 MHz, DMSO): 154.7, 143.1, 136.8, 136.4, 130.4, 129.3 (2C), 128.6, 127.6 (2C), 127.6, $119.2,118.9,109.5,101.2,32.5,21.0,14.5 . \mathrm{m} / \mathrm{z} \mathrm{MS}\left(\mathrm{ESI}^{+}\right): 342$ $(\mathrm{M}+\mathrm{H})^{+}, 364(\mathrm{M}+\mathrm{Na})^{+}$. HRMS $\left(\mathrm{ESI}^{+}\right): \mathrm{m} / \mathrm{z}$ calculated for $\mathrm{C}_{18} \mathrm{H}_{19} \mathrm{~N}_{3} \mathrm{NaO}_{2} \mathrm{~S}[\mathrm{M}+\mathrm{Na}]^{+}$364.1090; found 364.1105.

\section{General procedure for the synthesis of products $4 a-n$}

To a solution of $N$-tosylhydrazone $7 \mathbf{b}$-i $(1.5 \mathrm{mmol}), t$-BuOLi $(2.2$ $\mathrm{mmol}), \mathrm{PdCl}_{2}\left(\mathrm{CH}_{3} \mathrm{CN}\right)_{2}(0.1 \mathrm{mmol})$, and dppf $(0.2 \mathrm{mmol})$ in dioxane $(1 \mathrm{~mL})$ was added $\mathbf{5 a}, \mathbf{b}(1 \mathrm{mmol})$. The reaction vessel was sealed and then heated at $90{ }^{\circ} \mathrm{C}$ for $2 \mathrm{~h}$. The resulting suspension was cooled to room temperature and filtered through a pad of Celite, eluting with EtOAc, to remove the inorganic salts. After concentration, the reaction mixture was purified by silica gel chromatography.

4-[1-(4-Methoxy-phenyl)-vinyl]-2-methyl-quinazoline 4a: 
$50 \%$ yield; yellow oil, Rf 0.3 (Cyclohexane/EtOAc, 7/3). IR (neat, $\left.\mathrm{cm}^{-1}\right)$ : 1608, 1554, 1511, 1250, 1180. ${ }^{1} \mathrm{H}$ NMR $\left(300 \mathrm{MHz}, \mathrm{CDCl}_{3}\right)$ : $7.97(\mathrm{~d}, 1 \mathrm{H}, J=8.5 \mathrm{~Hz}), 7.87$ (d, $1 \mathrm{H}, J=8.5 \mathrm{~Hz}), 7.81$ (td, $1 \mathrm{H}, J=$ $8.5 \mathrm{~Hz}, J=0.9 \mathrm{~Hz}), 7.41(\mathrm{td}, 1 \mathrm{H}, J=8.3 \mathrm{~Hz}, J=0.9 \mathrm{~Hz}), 7.23(\mathrm{~d}$, $2 \mathrm{H}, J=8.9 \mathrm{~Hz}), 6.82(\mathrm{~d}, 2 \mathrm{H}, J=8.9 \mathrm{~Hz}), 6.04(\mathrm{~s}, 1 \mathrm{H}), 5.46(\mathrm{~s}, 1 \mathrm{H})$, 3.78 (s, 3H), 2.93 (s, 3H). ${ }^{13} \mathrm{C}$ NMR (75 MHz, $\mathrm{CDCl}_{3}$ ): 169.9, 164.1, 159.8, 151.1, 145.0, 133.9, 131.4, 128.1, 128.0 (2), 127.1, 126.7, 121.7, 116.9, $114.1(2 \mathrm{C}), 55.4,26.8 . \mathrm{m} / \mathrm{z} \mathrm{MS}(\mathrm{ESI}+)$ : $277(\mathrm{M}+\mathrm{H})^{+}$. HRMS $\left(\mathrm{ESI}^{+}\right): \mathrm{m} / \mathrm{z}$ calculated for $\mathrm{C}_{18} \mathrm{H}_{17} \mathrm{~N}_{2} \mathrm{O}[\mathrm{M}+\mathrm{H}]^{+}$277.1335; found 277.1335 .

\section{2-Methoxy-5-(1-(2-methylquinazolin-4-yl)vinyl)phenol $\mathbf{4 b}$}

Compound $\mathbf{4 b}$ was prepared by the coupling of $N$-tosylhydrazone 7a with $5 a$ (see the general procedure) followed by the deprotection of the-OTBS group: The resulting crude mixture after the coupling of $7 \mathbf{a}$ with 5 a was dissolved in $\mathrm{MeOH}(1 \mathrm{~mL})$ and $\mathrm{K}_{2} \mathrm{CO}_{3}$ (2 mmol) was added to the mixture, and stirring was continued for $6 \mathrm{~h}$. The resulting suspension was filtered and purified by silica gel chromatography. $34 \%$ yield, yellow oil, Rf 0.1 (Cyclohexane/EtOAc, 7/3). IR (neat, $\mathrm{cm}^{-1}$ ): 1615, 1554, 1512, 1439, 1279, 1135. ${ }^{1} \mathrm{H}$ NMR (300 MHz, $\left.\mathrm{CDCl}_{3}\right): 7.98$ (d, $1 \mathrm{H}, J=8.4$ $\mathrm{Hz}$ ), 7.87 (d, $1 \mathrm{H}, J=8.3 \mathrm{~Hz}$ ), 7.81 (td, $1 \mathrm{H}, J=7.1 \mathrm{~Hz}, J=1.2 \mathrm{~Hz}$ ), 7.42 (t, $1 \mathrm{H}, J=7.4 \mathrm{~Hz}$ ), 6.92 (s, 1H), 6.75 (s, 2H), 6.12 (brs, 1H), $6.04(\mathrm{~s}, 1 \mathrm{H}), 5.46(\mathrm{~s}, 1 \mathrm{H}), 3.87(\mathrm{~s}, 3 \mathrm{H}), 2.90(\mathrm{~s}, 3 \mathrm{H}) .{ }^{13} \mathrm{C}$ NMR $(75$ $\mathrm{MHz}, \mathrm{CDCl}_{3}$ ): 170.1, 164.0, 150.7, 147.1, 145.9, 145.0, 134.1, $132.3,127.8,127.1,126.9,121.8,118.9,117.4,113.0,110.8$, 56.1, 26.5. $\mathrm{m} / \mathrm{z} \mathrm{MS}\left(\mathrm{ESI}^{+}\right): 293(\mathrm{M}+\mathrm{H})^{+}$. HRMS $\left(\mathrm{ESI}^{+}\right): \mathrm{m} / \mathrm{z}$ calculated for $\mathrm{C}_{18} \mathrm{H}_{17} \mathrm{~N}_{2} \mathrm{O}_{2}[\mathrm{M}+\mathrm{H}]^{+}$293.1285; found 293.1293.

\section{4-[1-(3-Fluoro-4-methoxyphenyl)-vinyl]-2-methyl-quinazoline 4c}

$46 \%$ yield, yellow oil, Rf 0.2 (Cyclohexane/EtOAc, 7/3). IR (neat, $\left.\mathrm{cm}^{-1}\right): 1615,1554,1517,1275,1134,1027 .{ }^{1} \mathrm{H}$ NMR $(300 \mathrm{MHz}$, $\left.\mathrm{CDCl}_{3}\right): 7.99(\mathrm{~d}, 1 \mathrm{H}, J=8.3 \mathrm{~Hz}), 7.86-7.80(\mathrm{~m}, 2 \mathrm{H}), 7.46-7.41$ (td, $1 \mathrm{H}, J=7.2 \mathrm{~Hz}, J=1.0 \mathrm{~Hz}$ ), $7.13(\mathrm{dd}, 1 \mathrm{H}, J=12.5 \mathrm{~Hz}, J=2.2 \mathrm{~Hz}$ ), 6.96-6.92 (m, 1H), $6.85(\mathrm{t}, 1 \mathrm{H}, J=8.5 \mathrm{~Hz}), 6.06(\mathrm{~s}, 1 \mathrm{H}), 5.51$ (s, $1 \mathrm{H}), 3.86$ (s, 3H), 2.93 (s, 3H). ${ }^{13} \mathrm{C}$ NMR $\left(75 \mathrm{MHz}, \mathrm{CDCl}_{3}\right): 169.3$, 164.1, 154.1, 150.9 (d, 1C, $J=23.7 \mathrm{~Hz}), 147.9$ (d, 1C, $J=11.1$ $\mathrm{Hz}), 144.1,134.1,131.9$ (d, 1C, $J=6.3 \mathrm{~Hz}), 128.2,126.9,126.8$, $122.9(\mathrm{~d}, 1 \mathrm{CH}, J=3.3 \mathrm{~Hz}), 121.6,118.1,114.3(\mathrm{~d}, 1 \mathrm{C}, J=19.4$ $\mathrm{Hz}), 113.3(\mathrm{~d}, 1 \mathrm{C}, J=1.9 \mathrm{~Hz}), 56.4,26.7 .{ }^{19} \mathrm{~F}$ NMR $(188 \mathrm{MHz}$, CDCl3): -132.7. $\mathrm{m} / z \mathrm{MS}\left(\mathrm{APCl}^{+}\right): 295(\mathrm{M}+\mathrm{H})^{+}$. HRMS $\left(\mathrm{ESI}^{+}\right): \mathrm{m} / z$ calculated for $\mathrm{C}_{18} \mathrm{H}_{16} \mathrm{FN}_{2} \mathrm{O}[\mathrm{M}+\mathrm{H}]^{+}$295.1241; found 295.1252.

\section{2-Methoxy-5-(1-(2-methylquinazolin-4-yl)vinyl)aniline 4d}

Compound $\mathbf{4 d}$ was prepared by the coupling of $\mathrm{N}$-tosylhydrazone $7 \mathrm{e}$ with $\mathbf{5 a}$ (see the general procedure) followed by the deprotection of the -NHAc group: The resulting crude mixture after the coupling of $7 \mathrm{e}$ with $5 \mathrm{a}$ was dissolved in $\mathrm{MeOH}(1 \mathrm{~mL})$ and $\mathrm{KOH}$ (20 mmol) was added. The mixture was heated and stirred in sealed tube at $100{ }^{\circ} \mathrm{C}$ for $12 \mathrm{~h}$. The resulting suspension was filtered and purified by silica gel chromatography to furnished compound $\mathbf{4 d}$ as a yellow oil, $27 \%$ yield, Rf 0.1 (Cyclohexane/EtOAc, 7/3). IR (neat, $\mathrm{cm}^{-1}$ ): 1614, 1567, 1553, 1441, 1330, 1219. ${ }^{1} \mathrm{H}$ NMR $\left(300 \mathrm{MHz}, \mathrm{CD}_{3} \mathrm{COCD}_{3}\right): 7.94-7.84(\mathrm{~m}$, $3 \mathrm{H}), 7.52-7.46(\mathrm{~m}, 1 \mathrm{H}), 6.76-6.72(\mathrm{~m}, 2 \mathrm{H}), 6.54(\mathrm{dd}, 1 \mathrm{H}, J=8.3$ $\mathrm{Hz}, J=2.3 \mathrm{~Hz}$ ), $5.96(\mathrm{~s}, 1 \mathrm{H}), 5.33(\mathrm{~s}, 1 \mathrm{H}), 4.41$ (brs, 2H), 3.81 (s, $3 \mathrm{H}), 2.79$ (s, 3H). ${ }^{13} \mathrm{C}$ NMR $\left(75 \mathrm{MHz}, \mathrm{CD}_{3} \mathrm{COCD}_{3}\right): 170.7,164.6$, $152.1,148.2,147.1,138.5,134.4,133.1,128.9,127.8,127.3$, $122.9,116.6,116.1,113.0,111.0,55.8,26.6 . \mathrm{m} / \mathrm{z} \mathrm{MS}(\mathrm{APCl}+)$ :
$292(\mathrm{M}+\mathrm{H})^{+}$. HRMS $\left(E S I^{+}\right): m / z$ calculated for $\mathrm{C}_{18} \mathrm{H}_{18} \mathrm{~N}_{3} \mathrm{O}[\mathrm{M}+\mathrm{H}]^{+}$ 292.1444; found 292.1457.

\section{4-[1-(3,4-Dimethoxyphenyl)-vinyl]-2-methyl-quinazoline $4 \boldsymbol{e}$}

48\% yield, yellow oil, Rf 0.1 (Cyclohexane/EtOAc, 7/3). IR (neat, $\left.\mathrm{cm}^{-1}\right): 1554,1514,1464,1326,1221,1143 .{ }^{1} \mathrm{H}$ NMR $(300 \mathrm{MHz}$, $\left.\mathrm{CDCl}_{3}\right): 7.96(\mathrm{~d}, 1 \mathrm{H}, J=8.4 \mathrm{~Hz}), 7.87-7.78(\mathrm{~m}, 2 \mathrm{H}), 7.41(\mathrm{t}, 1 \mathrm{H}, J=$ $7.6 \mathrm{~Hz}), 6.97(\mathrm{~d}, 1 \mathrm{H}, J=1.6 \mathrm{~Hz}), 6.76-6.68(\mathrm{~m}, 2 \mathrm{H}), 6.03(\mathrm{~s}, 1 \mathrm{H})$, $5.48(\mathrm{~s}, 1 \mathrm{H}), 3.84(\mathrm{~s}, 3 \mathrm{H}), 3.41(\mathrm{~s}, 3 \mathrm{H}), 2.93(\mathrm{~s}, 3 \mathrm{H}) .{ }^{13} \mathrm{C}$ NMR $(75$ $\left.\mathrm{MHz}, \mathrm{CDCl}_{3}\right): 169.7,164.1,151.1,149.5,149.1,145.3,133.9$, 131.8, 128.1, 127.0, 126.7, 121.7, 120.1, 117.4, 111.1, 109.5, 56.0 (2C), 26.8. $\mathrm{m} / \mathrm{z} \mathrm{MS}\left(\mathrm{APCl}^{+}\right): 307(\mathrm{M}+\mathrm{H})^{+}$. HRMS $\left(\mathrm{ESI}^{+}\right): \mathrm{m} / \mathrm{z}$ calculated for $\mathrm{C}_{19} \mathrm{H}_{19} \mathrm{~N}_{2} \mathrm{O}_{2}[\mathrm{M}+\mathrm{H}]^{+} 307.1441$; found 307.1452 .

\section{4-[1-(3,5-Dimethoxy-phenyl)-vinyl]-2-methyl-quinazoline $4 f$}

$36 \%$ yield, white solid, M.p.: 89.1-91.2 ${ }^{\circ} \mathrm{C}$. $\quad$ Rf 0.3 (Cyclohexane/EtOAc, 7/3). IR (neat, $\mathrm{cm}^{-1}$ ): 1592, 1460, 1424, 1294, 1206, 1161. ${ }^{1} \mathrm{H}$ NMR (300 MHz, $\left.\mathrm{CDCl}_{3}\right): 7.96$ (d, $1 \mathrm{H}, J=8.4$ $\mathrm{Hz}$ ), 7.87-7.78 (m, 2H), $7.42(\mathrm{td}, 1 \mathrm{H}, J=8.1 \mathrm{~Hz}, J=1.0 \mathrm{~Hz}), 6.45$ $(\mathrm{d}, 2 \mathrm{H}, J=2.1 \mathrm{~Hz}), 6.41(\mathrm{~d}, 1 \mathrm{H}, J=2.0 \mathrm{~Hz}), 6.12(\mathrm{~s}, 1 \mathrm{H}), 5.58$ (s, $1 \mathrm{H}), 3.72(\mathrm{~s}, 6 \mathrm{H}), 2.93(\mathrm{~s}, 3 \mathrm{H}) .{ }^{13} \mathrm{C}$ NMR $\left(75 \mathrm{MHz}, \mathrm{CDCl}_{3}\right)$ : 169.3, $164.1,161.0$ (2C), 151.1, 145.7, 141.0, 134.0, 128.1, 127.0, 126.8, 121.7, 119.5, $105.4(2 \mathrm{C}), 100.2,55.5(2 \mathrm{C}), 26.8 . \mathrm{m} / z \mathrm{MS}\left(\mathrm{APCl}^{+}\right)$: $307(\mathrm{M}+\mathrm{H})^{+}$. HRMS $\left(\mathrm{ESI}^{+}\right): \mathrm{m} / z$ calculated for $\mathrm{C}_{19} \mathrm{H}_{19} \mathrm{~N}_{2} \mathrm{O}_{2}[\mathrm{M}+\mathrm{H}]^{+}$ 307.1441 ; found 307.1446 .

\section{2-Methyl-4-[1-(3,4,5-trimethoxyphenyl)-vinyl]-quinazoline $\mathbf{4 g}$}

$40 \%$ yield, yellow solid, M.p.: $127-128 \quad{ }^{\circ} \mathrm{C}$. Rf 0.2 (Cyclohexane/EtOAc, 7/3). IR (neat, $\mathrm{cm}^{-1}$ ): 1553, 1506, 1464, 1410, 1331, 1242, 1128. ${ }^{1} \mathrm{H}$ NMR (300 MHz, $\left.\mathrm{CDCl}_{3}\right): 7.97$ (d, $1 \mathrm{H}, J$ $=8.5 \mathrm{~Hz}), 7.90-7.80(\mathrm{~m}, 2 \mathrm{H}), 7.45(\mathrm{td}, 1 \mathrm{H}, J=8.2 \mathrm{~Hz}, J=1.1 \mathrm{~Hz})$, $6.54(\mathrm{~s}, 2 \mathrm{H}), 6.07(\mathrm{~s}, 1 \mathrm{H}), 5.56(\mathrm{~s}, 1 \mathrm{H}), 3.84(\mathrm{~s}, 3 \mathrm{H}), 3.72(\mathrm{~s}, 6 \mathrm{H})$, 2.94 (s, 3H). ${ }^{13} \mathrm{C}$ NMR $\left(75 \mathrm{MHz}, \mathrm{CDCl}_{3}\right): 169.3,164.1,153.4(2 \mathrm{C})$, $151.2,145.7,138.6,134.7,134.0,128.1,127.0,126.9,121.7$, 119.0, 104.5 (2C), 61.0, 56.3 (2C), 26.8. $\mathrm{m} / \mathrm{z} \mathrm{MS}\left(\mathrm{ESI}^{+}\right)$: $359(\mathrm{M}+$ $\mathrm{Na})^{+}$. HRMS $\left(\mathrm{ESI}^{+}\right): \mathrm{m} / \mathrm{z}$ calculated for $\mathrm{C}_{20} \mathrm{H}_{21} \mathrm{~N}_{2} \mathrm{O}_{3} \quad[\mathrm{M}+\mathrm{H}]^{+}$ 337.1547; found 337.1547.

\section{2-Methyl-4-(1-(4-(trifluoromethoxy)phenyl)vinyl)quinazoline $\mathbf{4 h}$}

78\%, yellow oil, Rf 0.3 (Cyclohexane/EtOAc, 7/3). IR (neat, $\mathrm{cm}^{-1}$ ): 1554, 1509, 1490, 1254, 1207, 1164. ${ }^{1} \mathrm{H}$ NMR $\left(300 \mathrm{MHz}, \mathrm{CDCl}_{3}\right)$ : $8.00(\mathrm{~d}, 1 \mathrm{H}, J=8.2 \mathrm{~Hz}), 7.85-7.82(\mathrm{~m}, 2 \mathrm{H}), 7.49-7.43(\mathrm{td}, 1 \mathrm{H}, J=$ $7.4 \mathrm{~Hz}, J=1.1 \mathrm{~Hz}), 7.36(\mathrm{~d}, 2 \mathrm{H}, J=8.9 \mathrm{~Hz}), 7.15(\mathrm{~d}, 2 \mathrm{H}, J=8.1$ $\mathrm{Hz}), 6.16(\mathrm{~s}, 1 \mathrm{H}), 5.62(\mathrm{~s}, 1 \mathrm{H}), 2.93(\mathrm{~s}, 3 \mathrm{H}) .{ }^{13} \mathrm{C} \mathrm{NMR}(75 \mathrm{MHz}$, $\left.\mathrm{CDCl}_{3}\right): 169.2,164.1,151.1,149.3,144.3,137.4,134.3,128.3$ (2C), 128.2, 127.1, 126.7, 121.6, 121.1 (2C), 120.4 (q, $J=256.5$ $\mathrm{Hz}), 119.9,26.8 .{ }^{19} \mathrm{~F} \mathrm{NMR}\left(188 \mathrm{MHz}, \mathrm{CDCl}_{3}\right):-58.23 . \mathrm{m} / \mathrm{z} \mathrm{MS}$ $\left(\mathrm{APCl}^{+}\right): 331(\mathrm{M}+\mathrm{H})^{+}$. HRMS $\left(\mathrm{ESI}^{+}\right): \mathrm{m} / \mathrm{z}$ calculated for $\mathrm{C}_{18} \mathrm{H}_{14} \mathrm{~F}_{3} \mathrm{~N}_{2} \mathrm{O}[\mathrm{M}+\mathrm{H}]^{+}$331.1053; found 331.1064.

\section{2-Methyl-4-(1-(4-(methylthio)phenyl)vinyl)quinazoline 4i}

$43 \%$ yield, yellow oil, Rf 0.4 (Cyclohexane/EtOAc, 7/3). IR (neat, $\left.\mathrm{cm}^{-1}\right): 1751,1554,1492,1326,1215 .{ }^{1} \mathrm{H}$ NMR $\left(300 \mathrm{MHz}, \mathrm{CDCl}_{3}\right)$ : $7.96(\mathrm{~d}, 1 \mathrm{H}, J=8.4 \mathrm{~Hz}), 7.83-7.76(\mathrm{~m}, 2 \mathrm{H}), 7.42-7.36(\mathrm{~m}, 1 \mathrm{H}), 7.20$ $(\mathrm{d}, 2 \mathrm{H}, J=8.6 \mathrm{~Hz}), 7.14(\mathrm{~d}, 2 \mathrm{H}, J=8.7 \mathrm{~Hz}), 6.09(\mathrm{~s}, 1 \mathrm{H}), 5.52$ (s, $1 \mathrm{H}), 2.91$ (s, 3H), 2.42 (s, 3H). ${ }^{13} \mathrm{C}$ NMR $\left(75 \mathrm{MHz}, \mathrm{CDCl}_{3}\right): 169.4$, $164.1,151.1,145.0,139.2,135.4,133.9,128.1,127.0$ (2C), 126.9, 126.8, 126.3 (2C), 121.6, 118.1, 26.7, 15.5. $\mathrm{m} / \mathrm{z} \mathrm{MS}\left(\mathrm{APCl}^{+}\right): 293$ $(\mathrm{M}+\mathrm{H})^{+}$. HRMS $\left(\mathrm{ESI}^{+}\right): \mathrm{m} / \mathrm{z}$ calculated for $\mathrm{C}_{18} \mathrm{H}_{17} \mathrm{~N}_{2} \mathrm{~S}[\mathrm{M}+\mathrm{H}]^{+}$ 293.1107; found 293.1119 . 


\section{2-Methyl-4-(1-(naphthalen-2-yl)vinyl)quinazoline 4j}

$36 \%$ yield, white solid, Mp.: $113.6{ }^{\circ} \mathrm{C}$. TLC: Rf 0.2 (Cyclohexane/EtOAc, 7/3). IR (neat, $\mathrm{cm}^{-1}$ ): 1614, 1568, 1490, 1325, 1168, 906. ${ }^{1} \mathrm{H}$ NMR $\left(300 \mathrm{MHz}, \mathrm{CDCl}_{3}\right): 8.01(\mathrm{~d}, 1 \mathrm{H}, J=8.4$ $\mathrm{Hz}), 7.86(\mathrm{~d}, 1 \mathrm{H}, J=8.4 \mathrm{~Hz}), 7.83-7.77(\mathrm{~m}, 3 \mathrm{H}), 7.68-7.65(\mathrm{~m}, 1 \mathrm{H})$, 7.60-7.57 (m, 2H), 7.46-7.34 (m, 3H), $6.28(\mathrm{~s}, 1 \mathrm{H}), 5.68(\mathrm{~s}, 1 \mathrm{H})$, 2.98 (s, 3H). ${ }^{13} \mathrm{C}$ NMR $\left(75 \mathrm{MHz}, \mathrm{CDCl}_{3}\right)$ : 169.6, 164.1, 151.1, $145.6,136.1,134.0,133.3,133.1,128.5,128.4,128.0,127.6$, 127.0, 126.8, 126.5, 126.4, 126.4, 124.1, 121.7, 119.3, 26.8. $\mathrm{m} / \mathrm{z}$ MS $\left(\mathrm{ESI}^{+}\right): 297(\mathrm{M}+\mathrm{H})^{+}$. HRMS $\left(\mathrm{ESI}^{+}\right): \mathrm{m} / z$ calculated for $\mathrm{C}_{21} \mathrm{H}_{17} \mathrm{~N}_{2}$ $[\mathrm{M}+\mathrm{H}]^{+}$297.1386; found 297.1393.

\section{2-Methyl-4-(1-(1-methyl-1H-indol-5-yl)vinyl)quinazoline $4 \boldsymbol{k}$}

$46 \%$ yield, red oil, Rf 0.2 (Cyclohexane/EtOAc, 7/3). IR (neat, $\mathrm{cm}^{-}$ $\left.{ }^{1}\right): 1612,1565,1490,1332,1246 .{ }^{1} \mathrm{H}$ NMR $\left(300 \mathrm{MHz}, \mathrm{CDCl}_{3}\right): 8.00$ (d, $1 \mathrm{H}, J=8.4 \mathrm{~Hz}$ ), 7.91 (dd, $1 \mathrm{H}, J=8.4 \mathrm{~Hz}, \mathrm{~J}=0.7 \mathrm{~Hz}$ ), 7.83-7.77 (ddd, $1 \mathrm{H}, J=8.4 \mathrm{~Hz}, J=6.9 \mathrm{~Hz}, J=1.4 \mathrm{~Hz}$ ), 7.50-7.49 (m, $1 \mathrm{H})$, 7.40-7.34 (ddd, $1 \mathrm{H}, J=8.4 \mathrm{~Hz}, J=6.7 \mathrm{~Hz}, J=1.3 \mathrm{~Hz}$ ), 7.30-7.27 (m, 2H), $7.03(\mathrm{~d}, 1 \mathrm{H}, J=3.1 \mathrm{~Hz}), 6.41(\mathrm{~d}, 1 \mathrm{H}, J=3.1 \mathrm{~Hz}), 6.12(\mathrm{~d}$, $1 \mathrm{H}, J=0.7 \mathrm{~Hz}$ ), $5.53(\mathrm{~d}, 1 \mathrm{H}, J=0.7 \mathrm{~Hz}), 3.77(\mathrm{~s}, 3 \mathrm{H}), 2.99(\mathrm{~s}, 3 \mathrm{H})$. ${ }^{13} \mathrm{C}$ NMR $\left(75 \mathrm{MHz}, \mathrm{CDCl}_{3}\right): 170.6,164.1,151.0,146.8,136.7$, 133.7, 130.7, 129.7, 128.6, 127.9, 127.4, 126.6, 121.9, 120.6, 119.7, 116.7, 109.5, 101.7, 33.0, 26.8. $\mathrm{m} / z \mathrm{MS}\left(\mathrm{APCl}^{+}\right): 300(\mathrm{M}+$ $\mathrm{H})^{+}$. HRMS $\left(\mathrm{ESI}^{+}\right): \mathrm{m} / z$ calculated for $\mathrm{C}_{20} \mathrm{H}_{18} \mathrm{~N}_{3}[\mathrm{M}+\mathrm{H}]^{+} 300.1495$; found 300.1500 .

\section{2-Chloro-4-[1-(4-methoxyphenyl)-vinyl]-quinazoline 4 I}

$46 \%$ yield, yellow brown oil, Rf 0.4 (Cyclohexane/EtOAc, 7/3). IR (neat, $\left.\mathrm{cm}^{-1}\right): 1673,1597,1511,1246,1175 .{ }^{1} \mathrm{H}$ NMR $(300 \mathrm{MHz}$, $\left.\mathrm{CDCl}_{3}\right): 8.0(\mathrm{dd}, 1 \mathrm{H}, J=8.5 \mathrm{~Hz}, J=1.1 \mathrm{~Hz}), 7.90-7.85(\mathrm{~m}, 2 \mathrm{H})$, 7.49 (td, $1 \mathrm{H}, J=8.5 \mathrm{~Hz}, J=1.1 \mathrm{~Hz}), 7.23(\mathrm{~d}, 2 \mathrm{H}, J=8.8 \mathrm{~Hz}), 6.84$ (d, $2 \mathrm{H}, J=8.8 \mathrm{~Hz}), 6.06(\mathrm{~s}, 1 \mathrm{H}), 5.55(\mathrm{~s}, 1 \mathrm{H}), 3.79(\mathrm{~s}, 3 \mathrm{H}) \cdot{ }^{13} \mathrm{C}$ $\operatorname{NMR}\left(75 \mathrm{MHz}, \mathrm{CDCl}_{3}\right): 173.1,160.1,157.3,152.7,144.2,135.1$, 131.1, 128.1 (2C), 128.1, 127.9, 127.5, 122.4, 118.6, 114.3 (2C), 55.4. $\mathrm{m} / \mathrm{zMS}\left(\mathrm{APCl}^{+}\right): 297(\mathrm{M}+\mathrm{H})^{+}$.

\section{2-Chloro-4-[1-(3,4-dimethoxyphenyl)-vinyl]-quinazoline $4 m$}

19\% yield, yellow oil, Rf 0.3 (Cyclohexane/EtOAc, 7/3). IR (neat, $\mathrm{cm}-1): 1665,1595,1563,1514,1465,1264,1143.1 \mathrm{H}$ NMR $(300$ $\mathrm{MHz}, \mathrm{CDCl} 3): 8.00(\mathrm{~d}, 1 \mathrm{H}, \mathrm{J}=8.9 \mathrm{~Hz}), 7.91-7.85(\mathrm{~m}, 2 \mathrm{H}), 7.49$ (td, $1 \mathrm{H}, \mathrm{J}=8.2 \mathrm{~Hz}, \mathrm{~J}=1.2 \mathrm{~Hz}), 6.95(\mathrm{~d}, 1 \mathrm{H}, \mathrm{J}=2.0 \mathrm{~Hz}), 6.77(\mathrm{~d}, 1 \mathrm{H}, J$ $=8.4 \mathrm{~Hz}), 6.71(\mathrm{dd}, 1 \mathrm{H}, \mathrm{J}=8.3 \mathrm{~Hz}, \mathrm{~J}=2.0 \mathrm{~Hz}), 6.05(\mathrm{~s}, 1 \mathrm{H}), 5.59$ (s, $1 \mathrm{H}), 3.86(\mathrm{~s}, 3 \mathrm{H}), 3.83(\mathrm{~s}, 3 \mathrm{H}) .13 \mathrm{C} \mathrm{NMR}\left(75 \mathrm{MHz}, \mathrm{CDCl}_{3}\right)$ : $172.8,157.2,152.7,149.7,149.2,144.5,135.2,131.5,128.0$, 128.0, 127.4, 122.4, 120.2, 119.2, 111.2, 109.6, 56.1, 56.0 . m/z MS $\left(\mathrm{APCl}^{+}\right): 327(\mathrm{M}+\mathrm{H})^{+}$. HRMS $\left(\mathrm{ESI}^{+}\right): \mathrm{m} / \mathrm{z}$ calculated for $\mathrm{C}_{18} \mathrm{H}_{16} \mathrm{CIN}_{2} \mathrm{O}_{2}[\mathrm{M}+\mathrm{H}]^{+}$327.0895; found 327.0904.

\section{2-Chloro-4-[1-(3,4,5-trimethoxyphenyl)-vinyl]-quinazoline $4 n$}

34\% yield, white solid, M.p.: 135.1-136 ${ }^{\circ} \mathrm{C}$. TLC: Rf 0.4 (Cyclohexane/EtOAc, 7/3). IR (neat, $\mathrm{cm}^{-1}$ ): 1580, 1528, 1401, 1316, 1277, 1243, 1121. ${ }^{1} \mathrm{H}$ NMR $\left(300 \mathrm{MHz}, \mathrm{CDCl}_{3}\right): 8.01(\mathrm{~d}, 1 \mathrm{H}, \mathrm{J}$ $=8.9 \mathrm{~Hz}), 7.92-7.87(\mathrm{~m}, 2 \mathrm{H}), 7.55-7.49(\mathrm{~m}, 1 \mathrm{H}), 6.52(\mathrm{~s}, 2 \mathrm{H}), 6.09$ (s, 1H), $5.66(\mathrm{~s}, 1 \mathrm{H}), 3.85(\mathrm{~s}, 3 \mathrm{H}), 3.66(\mathrm{~s}, 6 \mathrm{H}) .{ }^{13} \mathrm{C} \mathrm{NMR}(75 \mathrm{MHz}$, $\left.\mathrm{CDCl}_{3}\right): 172.4,157.2,153.5$ (2C), 152.7, 144.9, 138.8, 135.3, 134.3, 128.1 (2C), 127.3, 122.3, 120.8, 104.5 (2C), 61.1, 56.4 (2C). $\mathrm{m} / z \mathrm{MS}\left(\mathrm{ESI}^{+}\right): 357(\mathrm{M}+\mathrm{H})^{+}$. HRMS $\left(\mathrm{ESI}^{+}\right): \mathrm{m} / \mathrm{z}$ calculated for $\mathrm{C}_{19} \mathrm{H}_{18} \mathrm{CIN}_{2} \mathrm{O}_{3}[\mathrm{M}+\mathrm{H}]^{+}$357.1000; found 357.1010.

\section{General procedure for the synthesis of quinazolines 10a-d}

A solution of vinylquinazolines $\mathbf{4 a}, \mathbf{4 e}, \mathbf{4} \mathbf{f}$ and $\mathbf{4 g}(1 \mathrm{mmol})$ in EtOAc $(1 \mathrm{~mL})$ was hydrogenated, at atmospheric pressure, in the presence of $\mathrm{Pd} / \mathrm{C}(20 \%)$. After filtration over a pad of Celite, the solution was concentrated under reduced pressure, and the residue was purified by flash chromatography.

\section{4-[1-(4-Methoxyphenyl)-ethyl]-2-methyl-quinazoline 10a}

99\% yield, brown oil, Rf 0.4 (Cyclohexane/EtOAc, 7/3). IR (neat, $\left.\mathrm{cm}^{-1}\right): 2925,1612,1564,1511,1463,1247,1178 .{ }^{1} \mathrm{H}$ NMR (300 $\left.\mathrm{MHz}, \mathrm{CDCl}_{3}\right): 8.07(\mathrm{~d}, 1 \mathrm{H}, J=8.4 \mathrm{~Hz}), 7.91(\mathrm{~d}, 1 \mathrm{H}, J=8.4 \mathrm{~Hz})$, 7.75-7.69 (m, 1H), 7.45-7.39 (m, 1H),7.24 (d, 2H, J = 8.7 Hz), 6.79 (d, $2 \mathrm{H}, J=8.7 \mathrm{~Hz}$ ), 4.95 (q, $1 \mathrm{H}, J=6.9 \mathrm{~Hz}$ ), 3.71 (s, 3H), 2.92 (s, $3 \mathrm{H}), 1.78(\mathrm{~d}, 3 \mathrm{H}, J=6.9 \mathrm{~Hz}) \cdot{ }^{13} \mathrm{C} \mathrm{NMR}\left(75 \mathrm{MHz}, \mathrm{CDCl}_{3}\right): 172.4$, 163.8, 158.2, 150.7, 136.5, 133.0, 128.6 (2C), 128.5, 126.4, 124.6, 121.4, 114.1 (2C), 55.2, 42.2, 26.8, 21.3. $\mathrm{m} / z \mathrm{MS}\left(\mathrm{APCl}^{+}\right): 279(\mathrm{M}$ $+\mathrm{H})^{+}$. HRMS $\left(\mathrm{ESI}^{+}\right): \mathrm{m} / \mathrm{z}$ calculated for $\mathrm{C}_{18} \mathrm{H}_{19} \mathrm{~N}_{2} \mathrm{O}[\mathrm{M}+\mathrm{H}]^{+}$ 279.1492 ; found 279.1505 .

\section{4-[1-(3,4-dimethoxyphenyl)-ethyl]-2-methyl-quinazoline 10b}

97\% yield, yellow oil, Rf 0.2 (Cyclohexane/EtOAc, 7/3). IR (neat, $\left.\mathrm{cm}^{-1}\right): 1563,1514,1491,1418,1328,1262,1140 .{ }^{1} \mathrm{H}$ NMR $(300$ $\left.\mathrm{MHz}, \mathrm{CDCl}_{3}\right): 8.10(\mathrm{~d}, 1 \mathrm{H}, J=8.2 \mathrm{~Hz}), 7.90(\mathrm{~d}, 1 \mathrm{H}, J=8.3 \mathrm{~Hz})$, 7.75 (ddd, $1 \mathrm{H}, J=8.2 \mathrm{~Hz}, J=6.9 \mathrm{~Hz}, J=1.2 \mathrm{~Hz}$ ), 7.45 (ddd, $1 \mathrm{H}, J$ $=8.2 \mathrm{~Hz}, J=6.8 \mathrm{~Hz}, J=1.1 \mathrm{~Hz}), 6.92(\mathrm{~d}, 1 \mathrm{H}, J=2.0 \mathrm{~Hz}), 6.86$ (dd, $1 \mathrm{H}, J=8.2 \mathrm{~Hz}, J=2.0 \mathrm{~Hz}$ ), $6.75(\mathrm{~d}, 1 \mathrm{H}, J=8.2 \mathrm{~Hz}), 4.94$ (q, $1 \mathrm{H}, J=6.9 \mathrm{~Hz}), 3.82(\mathrm{~s}, 3 \mathrm{H}), 3.81(\mathrm{~s}, 3 \mathrm{H}), 2.91(\mathrm{~s}, 3 \mathrm{H}), 1.78(\mathrm{~d}$, $3 \mathrm{H}, \mathrm{J}=6.9 \mathrm{~Hz}) .{ }^{13} \mathrm{C}$ NMR $\left(75 \mathrm{MHz}, \mathrm{CDCl}_{3}\right): 172.3,163.8,150.8$, $149.1,147.8,137.0,133.2,128.6,126.5,124.7,121.4,119.8$, 111.3, 111.0, 56.0, 55.9, 42.6, 26.9, 21.4. $\mathrm{m} / z \mathrm{MS}\left(\mathrm{APCl}^{+}\right): 309(\mathrm{M}$ $+\mathrm{H})^{+}$. HRMS $\left(\mathrm{ESI}^{+}\right): \mathrm{m} / \mathrm{z}$ calculated for $\mathrm{C}_{19} \mathrm{H}_{21} \mathrm{~N}_{2} \mathrm{O}_{2}[\mathrm{M}+\mathrm{H}]^{+}$ 309.1598; found 309.1604.

\section{4-[1-(3,5-Dimethoxyphenyl)-ethyl]-2-methyl-quinazoline 10c}

$89 \%$ yield, brown oil, Rf 0.3 (Cyclohexane/EtOAc, 7/3). IR (neat, $\left.\mathrm{cm}^{-1}\right): 1609,1593,1564,1428,1205,1157 .{ }^{1} \mathrm{H}$ NMR $(300 \mathrm{MHz}$, $\left.\mathrm{CDCl}_{3}\right): 8.08(\mathrm{~d}, 1 \mathrm{H}, J=8.2 \mathrm{~Hz}), 7.90(\mathrm{~d}, 1 \mathrm{H}, J=8.4 \mathrm{~Hz}), 7.77-$ 7.72 (ddd, $1 \mathrm{H}, J=8.2 \mathrm{~Hz}, \mathrm{~J}=6.9 \mathrm{~Hz}, J=1.3 \mathrm{~Hz}$ ), 7.44 (ddd, $1 \mathrm{H}, J$ $=8.3 \mathrm{~Hz}, J=7.0 \mathrm{~Hz}, J=1.0 \mathrm{~Hz}), 6.49(\mathrm{~d}, 2 \mathrm{H}, J=2.2 \mathrm{~Hz}), 6.27$ (t, $1 \mathrm{H}, J=2.2 \mathrm{~Hz}$ ), 4.90 (q, 1H, J=6.9 Hz), $3.73(\mathrm{~s}, 6 \mathrm{H}), 2.91(\mathrm{~s}, 3 \mathrm{H})$, $1.78(\mathrm{~d}, 3 \mathrm{H}, J=6.9 \mathrm{~Hz}) .{ }^{13} \mathrm{C} \mathrm{NMR}\left(75 \mathrm{MHz}, \mathrm{CDCl}_{3}\right): 171.8,163.8$, 161.0 (2C), 150.7, 146.9, 133.2, 128.5, 126.6, 124.7, 121.6, 106.2 (2C), 98.0, $55.4(2 \mathrm{C}), 43.4,26.9,21.1 . \mathrm{m} / z \mathrm{MS}\left(\mathrm{APCl}^{+}\right): 309(\mathrm{M}+$ $\mathrm{H})^{+}$. HRMS $\left(\mathrm{ESI}^{+}\right): \mathrm{m} / z$ calculated for $\mathrm{C}_{19} \mathrm{H}_{21} \mathrm{~N}_{2} \mathrm{O}_{2}[\mathrm{M}+\mathrm{H}]^{+} 309.1598$; found 309.1610 .

\section{2-Methyl-4-[1-(3,4,5-trimethoxyphenyl)-ethyl]-quinazoline 10d}

97\% yield, yellow oil, Rf 0.2 (Cyclohexane/EtOAc, 7/3). IR (neat, $\left.\mathrm{cm}^{-1}\right)$ : 1587, 1564, 1492, 1461, 1420, 1328, 1238, 1122. ${ }^{1} \mathrm{H}$ NMR $\left(300 \mathrm{MHz}, \mathrm{CDCl}_{3}\right): 8.1$ (d, $\left.1 \mathrm{H}, J=8.2 \mathrm{~Hz}\right), 7.91(\mathrm{~d}, 1 \mathrm{H}, J=8.3 \mathrm{~Hz})$, 7.76 (ddd, $1 \mathrm{H}, J=8.2 \mathrm{~Hz}, \mathrm{~J}=7.1 \mathrm{~Hz}, J=1.3 \mathrm{~Hz}$ ), 7.47 (ddd, $1 \mathrm{H}, J$ $=8.2 \mathrm{~Hz}, J=7.0 \mathrm{~Hz}, J=1.2 \mathrm{~Hz}), 6.58(\mathrm{~s}, 2 \mathrm{H}), 4.91$ (q, $1 \mathrm{H}, J=6.9$ $\mathrm{Hz}), 3.79(\mathrm{~s}, 6 \mathrm{H}), 3.77(\mathrm{~s}, 3 \mathrm{H}), 2.91(\mathrm{~s}, 3 \mathrm{H}), 1.78(\mathrm{~d}, 3 \mathrm{H}, J=6.9$ $\mathrm{Hz}) .{ }^{13} \mathrm{C}$ NMR $\left(75 \mathrm{MHz}, \mathrm{CDCl}_{3}\right): 172.0,163.8,153.3(2 \mathrm{C}), 150.8$, 140.0, 136.8, 133.2, 128.6, 126.6, 124.6, 121.5, 105.0 (2C), 60.9, $56.2(2 \mathrm{C}), 43.2,26.8,21.5 . \mathrm{m} / z \mathrm{MS}\left(\mathrm{APCl}^{+}\right): 339(\mathrm{M}+\mathrm{H})^{+}$. HRMS $\left(\mathrm{ESI}^{+}\right): \mathrm{m} / \mathrm{z}$ calculated for $\mathrm{C}_{20} \mathrm{H}_{23} \mathrm{~N}_{2} \mathrm{O}_{3}[\mathrm{M}+\mathrm{H}]^{+}$339.1703; found 339.1705 . 


\section{Biology}

\section{Cell Culture and Proliferation Assay.}

Cancer cell lines were obtained from the American type Culture Collection (Rockville, MD) and were cultured according to the supplier's instructions. Human K562 leukemia, U87 glioblastoma, MCF7 breast cancer and HCT116 colorectal carcinoma cells were grown in RPMI 1640 containing 10\% FCS and 1\% glutamine. Human umbilical vein endothelial cells (HUVECs) were obtained from Clonetics (Lonza; Walkersville, MD, USA) and cultured according to the supplier's instructions. Cell lines were maintained at $37{ }^{\circ} \mathrm{C}$ in a humidified atmosphere containing $5 \% \mathrm{CO}_{2}$. Cell viability was assessed using Promega CellTiter-Blue TM reagent according to the manufacturer's instructions. Cells were seeded in 96-well plates $(5 \times 103$ cells/well) containing $50 \mu \mathrm{L}$ growth medium. After $24 \mathrm{~h}$ of culture, the cells were supplemented with $50 \mu \mathrm{L}$ of the tested compound dissolved in DMSO (less than $0.1 \%$ in each preparation). After $72 \mathrm{~h}$ of incubation, $20 \mu \mathrm{L}$ of resazurin was added for $2 \mathrm{~h}$ before recording fluorescence $(\lambda e x=560 \mathrm{~nm}, \lambda \mathrm{em}=$ $590 \mathrm{~nm}$ ) using a Victor microtiter plate fluorimeter (Perkin-Elmer, USA). The $\mathrm{Gl}_{50}$ corresponds to the concentration of the tested compound that caused a decrease of $50 \%$ in fluorescence of drug treated cells compared with untreated cells. Nonlinear regression graph was plotted between \% cell inhibition and Log10 concentration, and $\mathrm{IC}_{50}$ was determined using GraphPad Prism software. Experiments were performed in triplicate. The $\mathrm{GI}_{50}$ values for all compounds were compared to the $\mathrm{Gl}_{50}$ of $\mathrm{CA}-4$ and isoCA-4 and were measured the same day under the same conditions.

\section{Tubulin Binding Assay}

Sheep brain tubulin was purified according to the method of Shelanski $\left[{ }^{40}\right]$ by two cycles of assembly-disassembly and then diluted in the assembly buffer containing $0.1 \mathrm{M}$ MES, $0.5 \mathrm{mM}$ $\mathrm{MgCl}_{2}, 1 \mathrm{mM}$ EGTA, and $1 \mathrm{mM}$ GTP, $\mathrm{pH} 6.6$ to a final concentration around $2-3 \mathrm{mg} / \mathrm{mL}$. Tubulin assembly was monitored by fluorescence according to reported procedure $\left[{ }^{41}\right]$ using DAPI as fluorescent molecule. Assays were realized on 96-well plates prepared with Biomek NKMC and Biomek 3000 from Beckman Coulter and read at $37^{\circ} \mathrm{C}$ on Wallac Victor fluorimeter from Perkin Elmer. The $\mathrm{IC}_{50}$ value of each compound was determined as the concentration required to decrease the maximum assembly rate of tubulin by $50 \%$ compared to the rate in the absence of compound. The $\mathrm{IC}_{50}$ values for all compounds were compared to the $\mathrm{IC}_{50}$ of isoCA-4 and isoerianin measured the same day under the same conditions.

\section{Cell Cycle Analysis}

Exponentially growing HCT116 cancer cells were incubated with $4 \mathrm{~b}-\mathrm{d}$ at a concentration of 5,10 and $50 \mathrm{nM}$ or DMSO for $24 \mathrm{~h}$. Cell-cycle profiles were determined by flow cytometry on a FC500 flow cytometer (Beckman-Coulter, France) as described previously. ${ }^{[42]}$

\section{Apoptosis}

Apoptosis was measured by the Apo-one homogeneous caspase3/7 assay (Promega Co, WI) according to the manufacturer's recommendations. Briefly, U87 cells were subcultured on a 96-well plate with $5 \times 10^{4}$ cells/well in $100 \mu \mathrm{L}$ medium. After $24 \mathrm{~h}$ of incubation, the medium in the 96-well plate was discarded and replaced with medium containing $\mathbf{4 b} \mathbf{b} \mathbf{d}$ at a concentration of $25 \mathrm{nM}$ or $0.1 \%$ DMSO (as negative control). The U87 cells were incubated for $24 \mathrm{~h}$, each well then received $100 \mu \mathrm{L}$ of a mixture of caspase substrate and Apo-one caspase $3 / 7$ buffer. After $1 \mathrm{~h}$ of incubation, the fluorescence of sample was measured using a Victor microtiter plate fluorimeter (Perkin-Elmer, USA) at $527 \mathrm{~nm}$.

\section{Cord Disruption Assay}

HUVECs $\left(2 \times 10^{4}\right.$ cells per well) were plated in 96 -well plates on a thick layer of Matrigel (Becton Dickinson; $10 \mathrm{mg} \mathrm{mL}^{-1}, 60 \mu \mathrm{L}$ per well) and allowed to align for $24 \mathrm{~h}$. Quinazoline $4 \mathrm{~d}(50 \mathrm{nM})$ or DMSO (vehicle) were added to the formed cords and left for $1 \mathrm{~h}$. Images were taken $1 \mathrm{~h}$ after the addition of compounds.

\section{Molecular modeling}

X-ray structures of four different tubulin co-crystals were retrieved from the PDB ${ }^{[43]}$ (accession codes 1SA0, 1SA1, 3HKC, 3HKD and $3 \mathrm{HKE}$ ) and prepared using Protein Preparation Wizard workflow from Schrödinger suite ${ }^{[4]}$, including optimization of the hydrogen bond network and a short minimization with position restraints on heavy atoms using OPLS_2005 force field ${ }^{[45]}$. Coordinates for compounds $4 \mathrm{~b}-\mathrm{d}$ and $4 \mathrm{k}$ were generated using Standardizer from JChem suite v6.3. $1^{[46]}$ and geometries were refined at the HF/STO$3 G$ level ${ }^{[47]}$ using NWChem $v 6.1^{[48]}$ Ligands were then freely docked in the colchicine binding site located between chains $C$ and $D$ using the ensemble docking procedure available in GOLD v5.2.2 $2^{[49]}$ over the 5 aligned tubulin structures. CHEMPLP with default parameters was used as an objective function. ${ }^{[50]}$ Structures of complexes were exported, subjected to hydrogen bond network optimization and a short minimization with position restraints on heavy atoms using Protein Preparation Wizard, and loaded in Chimera $\mathrm{V}^{1.9\left[\mathrm{~S}^{51}\right]}$ for examination (including hydrogen bond detection, close contact analysis and representation of solventaccessible surface) and depiction.

\section{Acknowledgments}

The CNRS (Centre National de la Recherche Scientifique) is gratefully acknowledged for financial support of this research and ARC (Association pour la Recherche sur le Cancer) for a doctoral fellowship to M.S. The authors also thank la Ligue contre le Cancer for their financial support of this research throughout an "Equipe labellisée 2014" grant. Dr. Frédéric Leroux from University of Strasbourg (ECPM) is acknowledged for providing 1-bromo-4(trifluoromethoxy)benzene. Our laboratory BioCIS-UMR 8076 is a member of the Laboratory of Excellence LERMIT supported by a grant from the Agence Nationale de la Recherche, (ANR-10-LABX33).

Keywords: Quinazoline, Combretastatin, isoCA-4, Tubulin, Cytotoxicity, Cancer.

[1] G. R. Pettit, S. B. Singh, E. Hamel, C. M. Lin, D. S. Alberts, D. Garcia-Kendall, Experientia 1989, 45, 209-211.

[2] C.M. Lin, S.R. Singh, P.S. Chu, R.O. Dempcy, J.M. Schmidt, G.R Pettit, E. Hamel, Mol. Pharmacol. 1998, 34, 200-208.

[3] G. R. Pettit, M. R. Rhodes, D. L. Herald, E. Hamel, J. M. Schmidt, R. K. Pettit, J. Med. Chem. 2005, 48, 4087-4099.

[4] A. T. Mc Gown, B. W. Fox, Cancer Chemother. Pharmacol., 1990, 26 , 79-81.

[5] G.G. Dark, S.A. Hill, V.E. Prise, G.M. Tozer, G.R. Pettit, D.J. Chaplin, Cancer Res. 1997, 57,1829-1834.

[6] G.M. Tozer, V.E. Prise, J. Wilson, R.J. Locke, B. Vojnovic, M.R Stratford, M.F. Dennis, D.J. Chaplin, Cancer Res. 1999, 59, 16261634.

[7] G. R. Pettit, M. R. Rhodes, D. L. Herald, D. J. Chaplin, M. R. L. Stratford, E. Hamel, R. K. Pettit, J.-C. Chapuis, D. Oliva, Anti-Cancer Drug Des. 1998, 13, 981-993.

[8] K. Ohsumi, T. Hatanaka, K. Fujita, R. Nakagawa, Y. Fukuda, Y. Nihei, Y. Suga, Y. Morinaga, Y. Akiyama, T. Tsuji, Bioorg. Med. Chem. Lett. 1998, 8, 3153-3158.

[9] S. Aprile, E. Del Grosso, G. C. Tron, G. Grosa, Drug Metab. Dispos. 2007, 35, 2252-2261

[10] G. J. Rustin, S. M. Galbraith, H. Anderson, M. Stratford, L. K. Folkes, L. Sena, L. Gumbrell, P. M. Price, J. Clin. Oncol. 2003, 21, 28152822. 
[11] A. Dowlati, K. Robertson, M. Cooney, W. P. Petros, M. Stratford, J. Jesberger, N. Rafie, B. Overmoyer, V. Makkar, B. Stambler, A. Taylor, J. Waas, J. S. Lewin, K. R. McCrae, S. C. Remick, Cancer Res. 2002, 62, 3408-3416.

[12] G.C. Tron, T. Pirali, G. Sorba, F. Pagliai, S. Busacca, A.A. Genazzani, J. Med. Chem. 2006, 49, 3033-3044.

[13] C.B. Pattillo, Drugs Fut. 2011, 36, 385-390.

[14] A. Cirla, J. Mann, Nat. Prod. Rep. 2003, 20, 558-564.

[15] M.Marelli, F. Conforti, G.A. Statti, X. Cachet, S. Michel, F. Tillequin, F. Menichini, Curr. Med. Chem. 2011, 8, 3035-3081.

[16] C. Mousset, A. Giraud, O. Provot, A. Hamze, J. Bignon, J.-M. Liu, S. Thoret, J. Dubois, J.-D. Brion M. Alami., Bioorg. Med. Chem. Lett. 2008, 18, 3266-3271.

[17] O. Provot, A. Hamze, J.-F. Peyrat, J.-D. Brion, M. Alami, Anticancer Agents Med. Chem. 2013, 13, 1614-1635.

[18] S. Messaoudi, B. Tréguier, A. Hamze, O. Provot, J.-F. Peyrat, J. Rodrigo De Losada, J. M. Liu, J. Bignon, J. Wdzieczak-Bakala, S. Thoret, J. Dubois, J.-D. Brion, M. Alami, J. Med. Chem. 2009, 52, 4538-4542.

[19] A. Hamze, A. Giraud, S. Messaoudi, O. Provot, J.-F. Peyrat, J. Bignon, J.-M. Liu, J. Wdzieczak-Bakala, S. Thoret, J. Dubois, J.-D. Brion, M. Alami, ChemMedChem 2009, 4, 1912-1924.

[20] S. Messaoudi, A. Hamze, O. Provot, B. Tréguier, J. Rodrigo, J. Bignon, J.-M. Liu, J. Wdzieczak-Bakala, S. Thoret, J. Dubois, J.-D. Brion, M. Alami, ChemMedChem 2011, 6, 488-497.

[21] M.A. Soussi, O. Provot, G. Bernadat, J. Bignon, J. Wdzieczak-Bakala, D. Desravines, J. Dubois, J.-D. Brion, S. Messaoudi, M. Alami, Eur. J. Med. Chem. 2014, 78, 178-189.

[22] A. Maksimenko, M. Alami, F. Zouhiri, J.-D. Brion, A. Pruvost, J. Mougin, A. Hamze, T. Boissenot, O. Provot, D. Desmaële, P. Couvreur, ACS Nano, 2014, 8, 2018-2032.

[23] Y.-Q Gong, Y. Fan, D.-Z. Wu, H. Yang, Z.-B. Hu, Z.-T. Wang, Eur. J. Cancer, 2004, 40, 15541565.

[24] A.S. Negi, Y. Gautam, S. Alam, D. Chanda, S. Luqman, J. Sarkar, F. Khan, R. Konwar, Bioorg. Med. Chem. 2015, 23, 373-399.

[25] S. Kasibhatla, V. Baichwal, S.X. Cai, B. Roth, I. Skvortsova, S. Skvortsov, P. Lukas, N.E. English, N. Sirisoma, A. Pervin, B. Tseng, R.O. Carlson, C.M. Pleiman, Cancer Res. 2007, 67, 5865-5871.

[26] N. Sirisoma, A. Pervin, H. Zhang, S. Jiang, J.A. Willardsen, M.B. Anderson, G. Mathet, C.M. Pleiman, S. Kasibhatla, B. Tseng, J. Drewe, S.X. Cai, J. Med. Chem. 2009, 52, 2341-2351.

[27] K. Mahal, M. Resch, R. Ficner, R. Schobert, B. Biersack, T. Mueller, ChemMedChem, 2014, 9, 847-854.

[28] M. Alami, J.-D. Brion, S. Messaoudi, O. Provot, M. A. Soussi, J. Bignon, J. Dubois, J. Bakala-Wdzieczak, French Patent 1453142, 09 April 2014.

[29] a) J. Barluenga, P. Moriel, C. Valdés, F. Aznar, Angew. Chem. Int. Ed. 2007, 46, 5587-5590. b) M. Roche, A. Hamze, O. Provot, J.-D. Brion, M. Alami, J. Org. Chem. 2013, 78, 445-454. c) E. Rasolofonjatovo, B. Tréguier, O. Provot, A. Hamze, E. Morvan, J.-D. Brion, M. Alami, Tetrahedron Lett. 2011, 52, 1036-1040.

[30] B. Cook, D. Disalvo, D.R. Fandrick, C. Harcken, D. Kuzmich, T. Lee, P. Liu, J. Lord, C. Mao, J. Neu, B.C. Raudenbush, H. Razavi, J.T. Reeves, J. Song, A.D. Swinamer, Z. Tan, WO 2010/036632 A1.

[31] H. Reimlinger, W.R.F. Lingier, R. Merényi, Chem. Ber. 1975, 108, 3794-3798.

[32] M. Lawson, A. Hamze, J.-F. Peyrat, J. Bignon, J. Dubois, J.-D. Brion, M. Alami, Org. Biomol. Chem. 2013, 11, 3664-3673.

[33] A. Giraud, O. Provot, A. Hamze, J.-D. Brion, M. Alami, Tetrahedron Lett., 2008, 49, 1107-1110.

[34] E. Rasolofonjatovo, O. Provot, A. Hamze, J. Rodrigo, J. Bignon, J. Wdzieczak-Bakala, C. Lenoir, D. Desravines, J. Dubois, J.-D. Brion, M. Alami, Eur. J. Med. Chem. 2013, 62, 28-39.

[35] E. Rasolofonjatovo, O. Provot, A. Hamze, J. Rodrigo, J. Bignon, J. Wdzieczak-Bakala, D. Desravines, J. Dubois, J.-D. Brion, M. Alami, Eur. J. Med. Chem. 2012, 52, 22-32.

[36] A. B. S. Maya, C. Pérez-Melero, C. Mateo, D. Alonso, J.L. Fernández, C. Gajate, F. Mollinedo, R. Peláez, E. Caballero, M. Medarde, J. Med. Chem. 2005, 48, 556-568.

[37] a) A. Hamze, E. Rasolofonjatovo, O. Provot, C. Mousset, D. Veau, J. Rodrigo, J. Bignon, J.-M. Liu, J. Wdzieczak-Bakala, S. Thoret, J. Dubois, J-D. Brion, M. Alami, ChemMedChem, 2011, 6, 2179-2191. b) D. Renko, O. Provot, E. Rasolofonjatovo, J. Bignon, J. Rodrigo, J. Dubois, J.-D. Brion, A. Hamze, M. Alami, Eur. J. Med. Chem. 2015, $90,834-844$.

[38] Y. G. Tong, X. W. Zhang, M. Y. Geng, J. M. Yue, X L. Xin, T. Fang, S. Xu, L. J. Tong, M. H. Li, C. Zhang, W. H. Li, L. P. Lin, J. Ding, Mol. Pharmacol. 2006, 69, 1226-1233.

[39] K.M. Boatright, G.S. Salvesen, S. Guy, Curr. Opin. Cell. Biol. 2003, $15,725-731$.

[40] M. L. Shelanski, F. Gaskin, C. R. Cantor, Proc. Natl. Acad. Sci. U.S.A. 1973, 70, 765-768.

[41] D. M. Barron, S. K. Chatterjee, R. Ravindra, R. Roof, E. Baloglu, D. G. I. Kingston, S. Bane, Anal. Biochem. 2003, 315, 49-56.

[42] C. Venot, M. Maratrat, C. Dureuil, E. Conseiller, L. Bracco, L. Debussche, EMBO J. 1998, 17, 4668-4679.
[43] F. C. Bernstein, T. F. Koetzle, G. J. Williams, E. E. Meyer Jr., M. D. Brice, J. R. Rodgers, O. Kennard, T. Shimanouchi, M. Tasumi, J. Mol. Biol. 1977, 112, 535-542.

[44] a) Protein Preparation Wizard 2013-3; Epik version 2.4, Schrödinger, LLC, New York, NY, 2013; Impact version 5.9, Schrödinger, LLC, New York, NY, 2013; Prime version 3.2, Schrödinger, LLC, New York, NY, 2013. b) G. M. Sastry, M. Adzhigirey, T. Day, R. Annabhimoju, W. Sherman, J. Comput. Aid. Mol. Des. 2013, 27, 221-234. c) Protein pKa predictions were performed using PROPKA. M. H. M. Olsson, C. R. Søndergard, M. Rostkowski, J. H. Jensen, J. Chem. Theor. Comput. 2011, 7, 525-537.

[45] The OPLS_2005 parameters are described in J. L. Banks, H. S. Beard, Y. Cao, A. E. Cho, W. Damm, R. Farid, A. K. Felts, T. A Halgren, D. T. Mainz, J. R. Maple, R. Murphy, D. M. Philipp, M. P. Repasky, L. Y. Zhang, B. J. Berne, R. A. Friesner, E. Gallicchio, R. M Levy, J. Comp. Chem. 2005, 26, 1752-1780.

[46] JChem version 6.3.1, 2014, ChemAxon http://www.chemaxon.com

[47] a) C. C. J. Roothaan, Rev. Mod. Phys. 1951, 23, 69-89. b) W. J. Hehre, R. F. Stewart, J. A. Pople, J. Chem. Phys. 1969, 51, 2657 2664.

[48] M. Valiev, E. J. Bylaska, N. Govind, K. Kowalski, T. P. Straatsma, H. J. J. van Dam, D. Wang, J. Nieplocha, E. Apra, T. L. Windus, W. A de Jong, Comput. Phys. Commun. 2010, 181, 1477-1489.

[49] G. Jones, P. Willett, R. C. Glen, A. R. Leach, R. Taylor, J. Mol. Biol. 1997, 267, 727-748.

[50] O. Korb, T. Stützle, T. E. Exner, J. Chem. Inf. Model. 2009, 49, 84-96.

[51] a) Chimera is developed by the Resource for Biocomputing, Visualization, and Informatics at the University of California, San Francisco (supported by NIGMS P41-GM103311). E. F. Pettersen, T. D. Goddard, C. C. Huang, G. S. Couch, D. M. Greenblatt, E. C. Meng T. E. Ferrin, J. Comput. Chem. 2004, 25, 1605-1612. b) Solventexcluded molecular surfaces are created with the help of the MSMS package: M. F. Sanner, A. J. Olson, J. C. Spehner, Biopolymers 1996 38, 305-320 